\title{
Winning a deal in private equity: Do educational ties matter?
}

\author{
Florian Fuchs $^{\text {a }}$, Roland Füss ${ }^{\text {a, }}$, Tim Jenkinson ${ }^{\text {b, }}$, Stefan Morkoetter ${ }^{c}$ \\ ${ }^{\text {a }}$ University of St.Gallen, Switzerland \\ ${ }^{\mathrm{b}}$ University of Oxford, UK \\ ${ }^{\mathrm{c}}$ University of St.Gallen, Singapore \& Switzerland
}

\section{A R T I C L E I N F O}

\section{JEL codes:}

G11

G15

G24

G34

\section{Keywords:}

Buyout

Deal sourcing

Performance

Educational ties

Investment choice

\begin{abstract}
A B S T R A C T
In this paper, we investigate the role of educational ties in private equity. Although we cannot observe all the funds that bid for a target company, we construct the set of potential bidders based upon their size and investment cycle, as well as the location and sector of their target companies. By gathering detailed educational histories of fund partners and CEOs of target firms, we find a significantly higher incidence of educational ties in completed deals than exists among the set of potential bidders. We argue that educational ties between fund managers and CEOs of target companies play a (positive) role in sourcing deals and winning competitive transactions. The alma maters of CEOs and private equity partners are notably concentrated among the top universities, and we find that exclusivity of educational ties is important. However, we find no evidence that such educational ties produce higher returns for investors.
\end{abstract}

\section{Introduction}

Investors commit capital to private equity funds in order to gain access to valuable investment opportunities that may not be available to them through other channels. As the private equity sector has matured, there is increasing competition for deals with many transactions using a formal auction process, run by an intermediary. However, private equity funds also search for "proprietary" deals. In this paper, we explore the importance of one potential source of competitive advantage - educational ties - in both identifying and winning deals. However, the expected effect of educational ties on deal performance is not obvious as they can both provide access to private information and potentially bias a decision maker (e.g., Engelberg et al. (2012), Rousseau and Stroup (2015)). The value of educational ties to investors ultimately depends on whether they result in better returns, which we also analyze.

We focus on university ties and define them as a link between one or more of the private equity fund partners and the CEO of the target company. We do not limit our attention to contemporaneous attendance at university, but rather the potential impact of sharing

\footnotetext{
We thank the editor, Douglas Cumming, and two anonymous reviewers for several insightful comments, as well as PitchBook and an anonymous investor for providing access to their data. We are also grateful to Sridhar Arcot, Martin Brown, Georg Gebhardt, Andre Güttler, Gunter Löffler, Brian M. Lucey, Daniel Murphy, Per Östberg, Christine Scheef, Markus Schmid, and Thomas Zellweger as well as to the discussants and participants of the IFABS Asia Brunei Conference 2016, the 4th Paris Financial Management Conference 2016, the 14th Paris December Finance Meeting 2016, the PhD Seminar at the University of St.Gallen 2017, the 15th INFINITI Conference on International Finance 2017, the Research Seminar at Ulm University 2017, the 1st Annual Private Markets Research Conference at Lausanne 2017, and the 44th Annual Meeting of the European Finance Association 2017 for valuable comments.

* Corresponding author.

E-mail addresses: florian.fuchs@unisg.ch (F. Fuchs), roland.fuess@unisg.ch (R. Füss), tim.jenkinson@sbs.ox.ac.uk (T. Jenkinson), stefan. morkoetter@unisg.ch (S. Morkoetter).
} 
an alumni network. We analyze the importance of educational ties created by undergraduate, graduate and, separately, MBA degrees. Since we do not require such ties to involve direct interactions they could work through many alternative channels, from homophily ("birds of a feather flock together") to commonalities among the group of people attracted to an institution (Ishii and Xuan (2014)). Cohen and Malloy (2010) highlight that alumni networks are a particularly effective kind of social network that allows one to amass information about other graduates and common acquaintances due to self-selection into programs, which generates both a higher level of interaction and longer-lived relationships.

There is evidence that such ties are valuable in many other settings: mutual fund managers, security analysts, CEOs, and bankers all benefit from networks related to their previous educational experiences (e.g., Cohen et al. (2008, 2010), Butler and Gurun (2012), Engelberg et al. (2012)). More generally, personal and professional networks have been suggested as a powerful source of deal flow generation (e.g., Fenn et al. (1997), Teten and Farmer (2010), and Gompers et al. (2016a)), and research in the economic and sociological literature stresses the value of acquaintances or "weak ties" (Granovetter (1973, 1983)), especially for individuals in management positions (e.g., Wegener (1991), Brown et al. (2012)). Previous research has analyzed the importance of repeated business relationships for venture capital in the form of syndication networks (e.g., Sorensen and Stuart (2001, 2008), Hochberg et al. (2007, 2010), Hochberg et al. (2015)).

We employ a novel data set, which comprises the educational and professional histories of partners who manage private equity funds and CEOs of the target firms at the time of acquisition. Buyout funds and acquisition targets are primarily located in the United States and Western Europe, which are the two largest buyout markets. An important feature of the data is the allocation of partners at the fund rather than investment firm (General Partner) level. Management teams in private equity comprise a small number of experienced professionals who are highly incentivized by their own financial commitments and their compensation arrangements. Observing the allocation directly at the fund level reduces noise related to larger organizations that manage in parallel different funds across various asset classes. Our analysis focuses on traditional buyout and growth deals, excluding add-on and venture capital transactions due to their different dynamics. Target firms are public and private enterprises from various industry sectors and countries. We focus on investments up to 2010 to allow for sufficient time to measure subsequent performance. This leaves us with a final sample of 3051 investments comprising 2606 companies (with 2599 unique CEOs). A total of 1757 buyout funds from 904 unique investment firms compete for these investments (with 3939 unique partners).

Our main findings are as follows. First, we find that educational ties exist in $15 \%$ of buyout deals. Second, such ties increase the chance that a fund successfully closes the deal by $79 \%$ compared to a control group of benchmark funds, which could have acquired the same company but did not. We interpret the increased probability of an existing educational tie as a channel that helps buyout funds successfully to source a deal and close the transaction. Third, we find that the educational background of CEOs is less concentrated than that of private equity fund managers. For instance, more than $12 \%(4 \%)$ of the private equity managers (CEOs) went to Harvard University. Consequently, some educational ties are much less frequently observed than others. We define these ties as more exclusive and find that they are more present in deals that ultimately materialize. Fourth, the educational ties are more likely to be observed in acquisitions of private firms as compared to public-to-private deals.

Finally, we analyze the relevance of educational ties for investors by evaluating whether transactions with a pre-existing educational tie generate higher returns. The evidence suggests that the deal-sourcing channel is not a systematic driver for post-deal performance per se. This is not surprising, as it could imply that private equity funds are able to pay consistently less (or more) for companies where they had educational ties. Instead, we confirm the relevance of market timing, namely the length and the prevailing market return during the holding period. It seems that while buyout funds use educational ties for investment generation, post-deal returns are still primarily driven by market timing as well as the financial and operational value-enhancing measures that the funds implement during the lifetime of the investment. Our results are consistent with CEOs of target firms not accepting discounted offers from private equity managers sharing the same alma mater.

These results withstand several robustness tests. In particular, they remain when we control for previous experience of the partners in professional services firms and banks, where other networks are likely to arise. Furthermore, they hold when controlling for fund characteristics, such as size and sequence, for various plausible restrictions on deal and fund attributes, and for countries' legal and institutional frameworks, as well as different set-ups for our counterfactual approach.

The remainder of the paper is organized as follows. Section 2 discusses the institutional background, the data we use, and our counterfactual approach. Section 3 provides the main results. Section 4 presents a number of robustness checks, and Section 5 investigates whether deals sourced from educational networks perform better, or worse, than other deals. Section 6 concludes.

\section{Institutional background and data}

\subsection{Deal sourcing in the buyout industry}

The private equity industry has become an important asset class with more than $\$ 2.4$ trillion in assets under management, of which two-thirds are related to buyout and growth activity. ${ }^{1}$ Funds are typically set up as a limited liability partnership with a fixed lifetime of 10-12 years. The private equity manager acts as the general partner (GP) to the fund and receives an annual management fee and a share of the profits. While private equity managers can raise and manage more than one fund at a time, they usually assign several

${ }^{1}$ Source:Preqin (2016). 
partners to a specific fund. These partners are then responsible for the fund's deal sourcing activities as well as the management of its investments. The ability to identify and acquire good investment opportunities is one of the key capabilities of a successful private equity fund.

Fenn et al. (1997) outline that GPs compete with intermediaries (such as investment banks and deal brokers) to identify potential target firms. Intermediated deals tend to be less attractive as they are run as open auctions. Such deals often result in many PE firms competing for the transaction, with each incurring significant due diligence costs. In a related study, Teten and Farmer (2010) conclude that top-quartile funds have substantial scale in deal origination and a focus outside the most competitive markets. They report that personal and professional relationships provide half of the internal deal flow, followed by word-of-mouth and cold calls. More recently, Gompers et al. (2016a) survey a broad sample of GPs that identifies proprietary deals, where the fund acts as an exclusive buyer, as an important determinant of value creation. A third of deals are "proactively self-generated": 5-10\% originate from the fund managers' networks, with a similar proportion coming via the network of executives that funds work with. The remainder originates from agents and other private equity firms. However, despite the frequent notion of the importance of active deal sourcing and the role of networks across different studies, empirical evidence on the nature and influence of these relationships remains sparse.

The importance of deal sourcing has likely increased as the industry has grown and matured, and an increasing number of funds compete for the same investments. Metrick and Yasuda (2011) name the level of competition among funds as the main factor influencing performance, followed by financing conditions. In addition, competition for investment targets also originates from strategic acquirers that constantly monitor the market. Some authors report a recent decline in performance persistence (e.g., Harris et al. (2014), Braun et al. (2017)) indicating that it becomes more challenging to source promising investments. Other studies document a countercyclical relationship of capital and deal flow to fund performance (e.g., Phalippou (2007), Ljungqvist et al. (2009)). This likely drives funds to broaden deal sources and increasingly tap their own networks to close deals. Finally, Ishii and Xuan (2014) call for an extension of the traditional target-centered view by the acquirer-target relationship. In their study of corporate takeovers, the authors record that social ties influence both decision-making and subsequent merger performance.

\subsection{The role of educational ties}

There is a growing literature on networks in finance (see Allen and Babus (2009) for an overview). In particular, social and educational ties between the top management teams of different organizations or interest groups prove valuable across disciplines. ${ }^{2}$ For example, company outsiders, such as sell-side analysts, use them to initiate relationships with the senior management of public firms (Cohen et al. (2010)). Information transfer via ties allows banks and corporates to establish trust and reduce contracting frictions (Engelberg et al. (2012)). On the other hand, ties can also induce favoritism and introduce governance problems (e.g., Fracassi and Tate (2012), Butler and Gurun (2012)).

In terms of value, Engelberg et al. (2013) report that university ties are about four times more valuable than professional and other social ties. Furthermore, the authors do not find a significant difference between local and remote connections. Networks in general can likewise enlarge geographic exposure for their members (Cumming and Dai (2010)) and act as a barrier to enter a local market (Hochberg et al. (2010)).

In the public takeover market, Cai and Sevilir (2012) and Renneboog and Zhao (2014) find that board relationships influence the likelihood of a transaction and also performance. Ishii and Xuan (2014) extend the evidence to social ties. Cohen et al. (2008) note mutual fund managers invest heavily in firms with which they have an educational tie, while Sunesson (2009) reports an increased likelihood of matching a venture capitalist with an entrepreneur as well as with another venture capitalist. ${ }^{3}$ Bengtsson and Hsu (2015) find co-ethnicity to increase investment likelihood in venture capital, while Gompers et al. (2016b) investigate ethnic, educational, and career background for syndication. Lastly, Jääskeläinen and Maula (2014) report indirect ties to promote investment identification, while direct ties ease the investor's quality assessment.

Previous research has focused on the existence and value of social ties in the buyout industry. Stuart and Yim (2010) show that board networks influence the likelihood of becoming a target in a going-private transaction, while Wu (2011) finds that MBA ties transfer information among co-investors in deal syndication. Siming (2014) reports that past employment of managers in financial advisers provides access to profitable business opportunities. The amount of capital allocated to the buyout industry is significantly larger than that allocated to venture capital. Yet the relevance of educational ties in the buyout industry has, to the best of our knowledge, not been investigated so far. Driven by higher competition, fund managers invest more and more of their time into deal sourcing activities. Educational ties may give the buyout fund a competitive advantage in sourcing deals over other investors through easier target identification and reduced contracting frictions throughout the deal negotiation process.

Target identification via educational ties can help fund managers to successfully source proprietary transactions. Fund managers may actively use their alumni networks to screen for CEOs of potential buyout targets. Yet, we acknowledge that target identification is only the first step in a takeover process and does not guarantee the successful closing of a transaction. CEOs are bound to their fiduciary duties and cannot sell a company to a fellow alumna or alumnus from university without a proper process. We believe that in many

\footnotetext{
${ }^{2}$ In general, social networks serve three purposes: flow and quality of information, source of reward and punishment, and "trust" that others will do the "right" thing (Granovetter (2005)). Thus, they help to overcome asymmetric information, moral hazard, and costly search (Kuhnen (2009)).

${ }^{3}$ Besides social ties, the venture capital literature documents the value of economic ties (prior co-investments) and the role of spatial distance with regard to syndication networks. We refer to Sorensen and Stuart (2001, 2008), Hochberg et al. (2007, 2010), Chen et al. (2010), and Hochberg et al. (2015).
} 
cases the impact of any tie may be largely sub-conscious and would not have been referred to explicitly during the transaction. This leads to the second channel in the context of ties: reduced contracting frictions making it easier to close a transaction due to familiarities and shared values among the individuals involved. We link our argumentation to Stuart and Yim (2010) and argue that a favorable CEO facilitates a quick transaction. Trust may be established faster when parties share an educational tie, which in turn makes it easier to close a deal.

Whether such educational ties ultimately generate value for funds depends on the extent of competition and any favoritism towards those from the same university, which we investigate in Section 5.

\subsection{Data on funds and transactions}

The data we use in this study is sourced from PitchBook, a database for global M\&A, Private Equity and Venture Capital transactions. ${ }^{4}$ The four main components to our database are funds, partners, acquisition target firms and CEOs, and deal performance. We discuss these in turn.

First, we identify buyout funds for which information on their management teams is available and for which fund size, sequence, and location are not missing. This yields 1757 funds from 904 unique firms (General Partners) spanning vintage years from 1984 to $2010 .{ }^{5}$ We limit the sample period up to the vintage year 2010 to allow for sufficient time to measure subsequent performance. Table 1 breaks the fund sample down by vintage year. The average fund manages USD 794 million in capital (median: USD 316 million) and is the 4.5th fund of the general partner (median: 2.0). A quarter of funds are first-time funds and around two-thirds are based in the United States. Roughly one-half of funds provide performance information as an internal rate of return (IRR) and/or money multiple (TVPI) as a last reported figure. ${ }^{6}$ The average fund provides investors with an IRR of $13.3 \%$ (median: $12.0 \%$ ) and a total value of 1.62 times the paid-in capital (median: 1.54 ).

Second, Pitchbook lists 4333 unique individuals for the management teams of these funds (some are associated with multiple funds). An important feature of the data is the classification of individuals at the fund, rather than the general partner, level. The database sources this information from regulatory filings, fundraising information, investor websites and surveys, and complements it with the person's role and position within the firm, e.g., their role as lead partner or as a board member of portfolio firms. We follow the Pitchbook classification with a few exceptions where the partner carries an obvious non-managing title (e.g., Analyst, Associate), and refer to them collectively as partners of the fund. ${ }^{7}$ Our data also includes partners who have historically been involved even though the partner has left the fund in the meantime. The average management team of a fund in our sample consists of 3.5 partners (median: 3.0). For 3939 partners or $91 \%$ of the sample, a textual biography and educational background is available (we require at least the name of the academic institution).

Third, we compile a sample of investments of these buyout funds for which the target company CEO profile can be identified. The database is filtered based on the following criteria: (i) we include only buyout and growth/expansion transactions (this covers around $85 \%$ of initial deals and excludes venture capital); (ii) we include only companies that both identify the CEO at the time of the deal and list biography and education (around a third of transactions); (iii) as we only include funds up to vintage year 2010 we cannot fully model the competitive situation in the years after and, thus, exclude investments from subsequent years ${ }^{8}$; (iv) we exclude add-on transactions, which typically support a prior acquisition in a buy-and-build strategy and have different dynamics and determinants ${ }^{9} ;(v)$ we require non-missing values on deal date, company location and industry sector, and include only the first time a fund invests in a company in order to determine the initial contact point; (vi) we require investments to take place within five years

\footnotetext{
${ }^{4}$ PitchBook (www.pitchbook.com) obtains data from filings, press releases, and websites. Research teams collect, verify, and integrate the information and survey companies, advisers, investors, and lenders to cross-validate collected data. In a recent study, Brown et al. (2015) compare commercial private equity data sets of PitchBook, Preqin, Cambridge Associates, and Burgiss. They conclude that for North America all provide similar performance signals while outside coverage varies substantially. Harris et al. (2016) find the performance data of Burgiss and to Pitchbook qualitatively and quantitatively similar.

${ }^{5}$ We focus exclusively on buyout funds and therefore exclude buyout transactions undertaken by other types of investors (e.g., venture capital funds, angel investors). A buyout is defined as a transaction where a fund acquires a significant (often a controlling) equity stake in a business. Fund vintage indicates the year that a fund held its final close and/or began making investments. In total, the database lists 3,837 buyout funds (up to vintage year 2010). Our main restriction is that management teams should provide at least one partner's biography and education (passed by 2005 funds). Requiring fund size, sequence, and location leaves 1884 funds. Lastly, we remove 127 funds from the sample that do not pass our restrictions as potential matches in the counterfactual approach described below (i.e., they do not have at least one other investment in the industry and geographic region clusters or are not anymore in investment period). This results in a final sample of 1,757 funds.

${ }^{6}$ The internal rate of return (IRR) is the rate at which the net present value of all cash flows equals zero. Total value-to-paid-in (TVPI), also called investment multiple, represents the money returned to investors plus the unrealized investments relative to the capital contributed to the partnership.

7 Their actual job titles comprise a variety of titles, e.g., Founding Partner, Managing Partner, Partner, Managing Director, Senior Partner, Investment Director, Director, Operating Partner, Managing Principal, Principal, or General Partner (list not exhaustive).

${ }^{8}$ For example, when a fund with a vintage year vintage year 2010 acquires a company during 2012 it is likely that also funds with vintage year 2011 compete for it. However, these are excluded from the sample due to the required time lag on performance. While this essentially excludes the majority of investments from funds in the last years of the sample, it is a necessary condition to fully reflect the competitive situation.

${ }^{9}$ For example, the management of the acquiring portfolio company is actively involved and firms differ particularly in terms of firm size, profitability, and leverage (e.g., Morkoetter and Wetzer (2015)).
} 


\section{Table 1}

Breakdown of buyout fund sample by vintage year.

The table shows for each vintage year descriptive statistics on the buyout funds available in the PitchBook database (up to vintage year 2010). The sample is restricted to funds for which the management team can be identified, for which size, sequence, and location is non-missing, and which are only closed, fully invested and liquidated. Fund count reports a total count of funds and on the ones for which an IRR and a TVPI multiple is available, respectively. Fund profile lists the average sequence number, the number of partners tagged to the fund, the number of investments, as well as the average and median size. The count of investments includes all types of investments (incl. venture and add-on transactions) and is not restricted to the set of buyout and growth transactions used in the empirical part of the study. Fund performance depicts the average and median IRR and TVPI multiple for each vintage year. Performance and capital variables are winsorized at the $1 \%$ level. A split between U.S. based funds and international funds is provided at the bottom.

\begin{tabular}{|c|c|c|c|c|c|c|c|c|c|c|c|c|}
\hline \multicolumn{4}{|c|}{ Fund count } & \multicolumn{5}{|c|}{ Fund profile } & \multicolumn{4}{|c|}{ Fund performance } \\
\hline Vintage & Total & $\mathrm{w} /$ & $\mathrm{w} /$ & Avg & Avg & Avg & Avg & Med & Avg & Med & Avg & Med \\
\hline \multirow[t]{2}{*}{ Year } & Funds & IRR & TVPI & Seq. & Partn. & Invest & Size & Size & IRR & IRR & TVPI & TVPI \\
\hline & \# & \# & \# & \# & \# & \# & $\$ m$ & $\$ m$ & $\%$ & $\%$ & $x$ & $x$ \\
\hline 1984 & 2 & 0 & 0 & 1.5 & 1.0 & 3.5 & 48 & 48 & - & - & - & - \\
\hline 1985 & 1 & 0 & 0 & 1.0 & 1.0 & 1.0 & 16 & 16 & - & - & - & - \\
\hline 1986 & 4 & 0 & 0 & 1.5 & 1.8 & 4.2 & 76 & 82 & - & - & - & - \\
\hline 1987 & 8 & 7 & 4 & 3.1 & 1.2 & 9.1 & 1126 & 112 & 20.1 & 18.9 & 2.41 & 2.49 \\
\hline 1988 & 0 & 0 & 0 & - & - & - & - & - & - & - & - & - \\
\hline 1989 & 6 & 4 & 3 & 2.8 & 2.2 & 6.3 & 603 & 242 & 22.4 & 20.0 & 3.05 & 2.38 \\
\hline 1990 & 4 & 0 & 0 & 1.5 & 2.0 & 7.8 & 126 & 108 & - & - & - & - \\
\hline 1991 & 4 & 3 & 3 & 1.0 & 1.0 & 5.8 & 205 & 196 & 22.6 & 33.8 & 2.40 & 2.67 \\
\hline 1992 & 7 & 4 & 3 & 2.4 & 1.4 & 5.4 & 347 & 114 & 9.9 & 24.6 & 1.77 & 1.39 \\
\hline 1993 & 12 & 9 & 7 & 4.4 & 1.7 & 10.8 & 567 & 332 & 25.5 & 25.6 & 2.45 & 2.12 \\
\hline 1994 & 16 & 7 & 7 & 3.1 & 1.8 & 10.8 & 381 & 162 & 23.1 & 24.0 & 2.99 & 3.00 \\
\hline 1995 & 22 & 8 & 8 & 2.6 & 2.2 & 9.7 & 369 & 208 & 26.6 & 26.6 & 2.45 & 2.37 \\
\hline 1996 & 36 & 19 & 16 & 2.2 & 1.9 & 12.1 & 486 & 240 & 11.7 & 10.4 & 1.53 & 1.30 \\
\hline 1997 & 54 & 22 & 27 & 3.2 & 1.9 & 9.4 & 687 & 278 & 7.8 & 9.1 & 1.44 & 1.40 \\
\hline 1998 & 76 & 42 & 36 & 3.0 & 2.5 & 13.6 & 569 & 286 & 8.2 & 8.8 & 1.61 & 1.46 \\
\hline 1999 & 85 & 45 & 44 & 3.5 & 2.6 & 14.0 & 593 & 305 & 13.4 & 13.1 & 1.72 & 1.69 \\
\hline 2000 & 117 & 61 & 62 & 4.0 & 3.0 & 18.4 & 893 & 327 & 14.7 & 12.7 & 1.85 & 1.78 \\
\hline 2001 & 74 & 40 & 40 & 3.8 & 3.8 & 17.7 & 739 & 266 & 24.5 & 24.3 & 2.15 & 2.13 \\
\hline 2002 & 78 & 30 & 32 & 4.6 & 3.0 & 14.6 & 612 & 208 & 19.2 & 17.1 & 1.79 & 1.74 \\
\hline 2003 & 70 & 34 & 39 & 3.5 & 3.8 & 17.8 & 799 & 300 & 21.2 & 17.8 & 1.85 & 1.71 \\
\hline 2004 & 98 & 40 & 43 & 3.5 & 2.8 & 15.2 & 589 & 297 & 14.7 & 12.4 & 1.86 & 1.72 \\
\hline 2005 & 152 & 72 & 90 & 5.1 & 4.3 & 20.0 & 953 & 362 & 9.4 & 9.1 & 1.51 & 1.44 \\
\hline 2006 & 211 & 99 & 121 & 5.0 & 4.1 & 17.2 & 1044 & 421 & 8.9 & 8.9 & 1.49 & 1.50 \\
\hline 2007 & 227 & 108 & 129 & 5.0 & 4.2 & 18.4 & 920 & 327 & 11.5 & 10.5 & 1.50 & 1.46 \\
\hline 2008 & 188 & 81 & 102 & 6.2 & 4.0 & 16.1 & 937 & 325 & 11.6 & 12.0 & 1.42 & 1.44 \\
\hline 2009 & 104 & 47 & 57 & 4.5 & 3.8 & 15.8 & 865 & 300 & 15.8 & 14.3 & 1.47 & 1.42 \\
\hline 2010 & 101 & 44 & 62 & 5.3 & 4.1 & 14.3 & 488 & 333 & 9.6 & 9.5 & 1.35 & 1.27 \\
\hline Total & 1,757 & 826 & 935 & 4.5 & 3.5 & 16.1 & 794 & 316 & 13.3 & 12.0 & 1.62 & 1.54 \\
\hline U.S. & 1,115 & 608 & 666 & 3.8 & 3.6 & 17.3 & 791 & 319 & 13.5 & 12.5 & 1.63 & 1.58 \\
\hline Other & 642 & 218 & 269 & 5.6 & 3.4 & 13.9 & 800 & 313 & 12.6 & 10.4 & 1.60 & 1.44 \\
\hline
\end{tabular}

following the vintage year of the fund (this is enforced for consistency with the counterfactual approach, as described in Section 2.5).

This leaves us with a final sample of 3051 transactions comprising 2606 companies and 2599 individual CEOs (some firms are involved in multiple deals and within one transaction several funds can invest). ${ }^{10}$ Table 2 presents a break-down of the investments by geography, industry sector, transaction and deal type, and year. Around two-thirds of transactions involve companies based in North America with almost all the remaining being European-based. The industry split exhibits a high concentration on business and consumer services, followed by the information technology and healthcare sectors. In terms of transaction type, we observe that $7 \%$ of investments represent a delisting of a public company ('public to private'). Around $12 \%$ of deals are classified as management buyout/ in and $13 \%$ as secondary buyouts, and in $42 \%$ of cases the fund invests alongside another fund (conversely, 58\% are solo deals). Investment years range from 1987 up to 2010 yet most of our investments take place in the post-2000 period.

Fourth, we add deal-level returns to the investment sample. However, it is important to note that the availability of deal-level data in private equity is limited at present, with most information only being available at the fund level. The data that we construct is sourced from PitchBook and Preqin and complemented with data from one anonymous limited partner. This approach yields a total of 535 deal-level IRRs (mean: 29\%, median: $20 \%$ ) and 624 TVPI multiples (mean: $3.0 \times$, median: $2.4 \times$ ). ${ }^{11}$ The average holding duration is

\footnotetext{
10 The database lists a total of 24,506 buyout and growth/expansion transactions from 19,866 companies for our sample of buyout funds. The major restrictions are the requirement on CEO data and the exclusion of add-on transactions and investments after 2010 (combined $85 \%$ of excluded deals).

11 The variables are winsorized at the $1 \%$ tail.
} 
Table 2

Characteristics of the investment sample.

The table presents descriptive statistics on buyout and growth transactions where a buyout fund invests for the first time in the target company. Add-on transactions and investments after 2010 are excluded. Educational background of at least one partner of the investing fund and the target company CEO must be available to be included. Transactions without a date or missing information on the company's location and industry as well as funds with missing location or size are excluded. In addition, only deals where the investment took place within the five-year period following the fund's vintage year are considered for comparability with the counterfactual investment sample. Headquarter region, industry sector, investment year, and transaction type are based on classifications in the database. Geographic distance is the distance between the firm's headquarters and the closest partner of the acquiring fund, while deal type indicates whether one or multiple funds are involved in the transaction, respectively.

\begin{tabular}{|c|c|c|}
\hline & $N$ & $\%$ \\
\hline Total & 3051 & \\
\hline \multicolumn{3}{|l|}{ Panel A: Headquarter Region } \\
\hline North America & 2,065 & 67.68 \\
\hline Western Europe & 551 & 18.06 \\
\hline Northern Europe & 187 & 6.13 \\
\hline Eastern/Southern Europe & 130 & 4.26 \\
\hline Other regions & 118 & 3.87 \\
\hline \multicolumn{3}{|l|}{ Panel B: Geographic Distance } \\
\hline Distance $0-100 \mathrm{~km}$ & 730 & 23.93 \\
\hline Distance $101-500 \mathrm{~km}$ & 633 & 20.75 \\
\hline Distance $501-1000 \mathrm{~km}$ & 458 & 15.01 \\
\hline Distance $1001-2500 \mathrm{~km}$ & 709 & 23.24 \\
\hline Distance $>2500 \mathrm{~km}$ & 521 & 17.08 \\
\hline \multicolumn{3}{|l|}{ Panel C: Primary Industry Sector } \\
\hline Business Products and Services (B2B) & 1,000 & 32.78 \\
\hline Consumer Products and Services (B2C) & 730 & 23.93 \\
\hline Energy & 119 & 3.90 \\
\hline Financial Services & 259 & 8.49 \\
\hline Healthcare & 352 & 11.54 \\
\hline Information Technology & 461 & 15.11 \\
\hline Materials and Resources & 130 & 4.26 \\
\hline \multicolumn{3}{|l|}{ Panel D: Transaction Type } \\
\hline Buyout/LBO & 916 & 30.02 \\
\hline Divestiture/Carveout & 269 & 8.82 \\
\hline Management Buyout/-in & 363 & 11.90 \\
\hline Growth/Expansion & 578 & 18.94 \\
\hline Public to Private & 208 & 6.82 \\
\hline Recapitalization/Acquisition Financing & 320 & 10.49 \\
\hline Secondary Buyout & 397 & 13.01 \\
\hline \multicolumn{3}{|l|}{ Panel E: Deal Type } \\
\hline Solo & 1,755 & 57.52 \\
\hline Club & 1,296 & 42.48 \\
\hline \multicolumn{3}{|l|}{ Panel F: Investment Year } \\
\hline 1987-1994 & 27 & 0.88 \\
\hline $1995-2000$ & 340 & 11.14 \\
\hline 2001-2002 & 201 & 6.59 \\
\hline 2003-2004 & 387 & 12.68 \\
\hline 2005-2006 & 664 & 21.76 \\
\hline 2007-2008 & 777 & 25.47 \\
\hline 2009-2010 & 655 & 21.47 \\
\hline
\end{tabular}

6 years and the deal sample covers around 250 different funds, 55\% are U.S. based and less than 10\% are first-timers, from approximately 150 unique general partners. ${ }^{12}$ While this data can give only a glimpse into the deal return structure of buyout funds, it still provides us with insights into the role of educational networks for subsequent investment performance. Ideally, one would also

\footnotetext{
$\overline{12}$ Braun et al. (2017) recently presented a broad sample of deal-level returns in their investigation of performance persistence. Their data shows a median multiple of 1.9 for realized investments and higher multiples for the 2000-2004 period (median of 2.0) compared to the 2005-2013 period (median of 1.5).
} 
complement these ex-post returns with an analysis of entry valuations to test the role of educational ties for information transfer purposes. However, we have not been able to source such data for a sufficient coverage of our investment sample. Finally, as the performance data is not available for the complete data set, we will address concerns about a possible introduction of selection bias into our results in the later discussion of robustness checks.

\subsection{Biographies of partners and CEOs}

The information on each individual in the database comprises the name, a textual biography, and a list of educational achievements. The latter split the degree institutions by name, type, field, and year. ${ }^{13}$ Table 3 presents the most frequently observed institutions for both partners and the target company CEOs. A majority of managers graduated from well-known institutions and most have more than one academic degree. The fund partners are more likely to have an MBA degree compared to their corporate counterparts. They are also much more concentrated on a selected number of institutions and this concentration is even more pronounced for MBA degrees. Harvard, especially, enjoys a significant presence, heading both lists with the highest number of graduates. These findings are consistent with earlier studies on senior managers in mutual funds and venture capital funds (e.g., Cohen et al. (2008, 2010), Sunesson (2009), Zarutskie (2010)). We highlight this point as our analysis requires the fund partners and target firm CEOs to graduate from the same academic institution in order to create an educational tie. We focus our analysis on the educational tie between CEO and a fund partner as the CEO position matters most in an M\&A context. It is rare that transactions are executed without the explicit involvement and support of a target firm's CEO. We acknowledge that our exclusive focus on CEO-related ties ignores the potential existence of other ties, most notably between fund partners and members of the board of directors of the target company. We relate in this context to the existing research on board networks (see also Cai and Sevilir (2012) and Renneboog and Zhao (2014)) and call for future research to explore the importance of board of directors' ties in buyout transactions.

The value of the educational attainment for deal sourcing may also depend on the partner's previous professional experience. To account for this, we examine the (relationship oriented) work history of the partners with regard to professional services firms and banks. Specifically, we parse experience in management/strategy consulting, in a major accounting firm, and in an (investment) bank. ${ }^{14}$ We observe more than half of the funds in our sample have at least one partner with prior banking experience, a quarter with a consulting firm, and a fifth with a major accounting firm (team means are 33\%, 11\%, and 7\%, respectively). The previous professional experience of CEOs is much more varied, with many having worked mainly in industrial sectors.

\subsection{Counterfactual approach}

Ideally, we would be able to identify all funds that evaluated a target firm and subsequently participated in the bidding process. As this information is not available, we use a counterfactual approach. We identify funds with a suitable profile that could have invested in the target firm as well and are also competitors to the winning fund. This approach follows the literature on social, board and syndication ties (e.g., Gompers and Xuan (2009), Sunesson (2009), Stuart and Yim (2010), Siming (2014), Bengtsson and Hsu (2015), Gompers et al. (2016b)). ${ }^{15}$ We assess whether educational ties between the management teams of the fund and the target firm give the fund an edge over other potential bidders during this deal generation process.

We create our set of counterfactual investments in a similar way to Bengtsson and Hsu (2015) and set out the following three criteria: (i) the deal takes place during a fund's investment period, which we define as the 5 -year period following the vintage year, ${ }^{16}$ (ii) the fund makes at least one other investment in the same geographic region, and (iii) the fund makes at least one other investment

\footnotetext{
${ }^{13}$ Graduation year is only available for half of the degrees and the textual biography does not allow to determine the manager's age or origin. We omit gender and ethnicity in the analysis since the large majority of partners and CEOs are male and we do not expect a significant effect from cultural differences.

${ }^{14}$ Consulting includes McKinsey \& Co, BCG, Bain \& Co, Oliver Wyman, Roland Berger, Booz/Strategy\&, and L.E.K., whereas accounting comprises PwC, Deloitte, KPMG, EY, and Arthur Anderson. Banking is based on a list of 50 global banks compiled by "The Banker" as well as major investment banks such as Lehman Brothers, Bear Stearns, Lazard, Rothschild (list not exhaustive).

${ }^{15}$ Gompers and Xuan (2009) investigates the likelihood of becoming the acquisition target of a public company, while Sunesson (2009) uses a cross-section from 2002 to investigate the matching behavior between venture capitals with entrepreneurs as well as with other venture capitalists. Stuart and Yim (2010) relate board interlocks with the probability of going private transaction. Siming (2014) simulates the mandates of financial advisers by private equity firms. Bengtsson and Hsu (2015) analyze ethnic matching between entrepreneurial founders and venture capital partners in the U.S., and Gompers et al. (2016b) the syndication likelihood among venture capital partners. While this approach is typically applied in the literature rather than spatial econometrics or more advanced network modeling techniques, one of its limitations is that the (relative) position of nodes within the network cannot be captured.

${ }^{16}$ Private equity funds usually have a lifetime of 10-12 years and invest in the first five years after the fund's initial set-up. (e.g., Metrick and Yasuda (2010)).
} 


\section{Table 3}

Degree institutions of fund partners and CEOs.

The table presents the most frequent academic institutions from which fund partners and target company CEOs have received their academic degrees. Individuals can be represented with multiple degrees but are counted only once even in case a partner or CEO is involved in several funds and transactions, respectively. Fund Partners represent the individuals that are involved in the management of a buyout fund up to vintage year 2010 (see Table 1). Target Firm CEO refers to the individual that was in this role at the time of the deal where one of the buyout funds invested in the company for the first time. This includes only buyout and growth transactions up to 2010 and excludes add-on transactions. The table only lists institutions where one of the two groups is represented with at least 50 degrees.

\begin{tabular}{|c|c|c|c|c|c|c|c|c|c|}
\hline & \multirow[b]{2}{*}{ Academic Institution } & \multicolumn{4}{|c|}{ Fund Partners } & \multicolumn{4}{|c|}{ Target Firm CEO } \\
\hline & & $N$ & $\%$ & MBA & $\%$ & $N$ & $\%$ & MBA & $\%$ \\
\hline 1 & Harvard University & 877 & 12.29 & 593 & 28.59 & 166 & 4.10 & 94 & 12.62 \\
\hline 2 & University of Pennsylvania & 487 & 6.82 & 221 & 10.66 & 63 & 1.56 & 27 & 3.62 \\
\hline 3 & Stanford University & 306 & 4.29 & 163 & 7.86 & 63 & 1.56 & 18 & 2.42 \\
\hline 4 & Columbia University & 177 & 2.48 & 114 & 5.50 & 40 & 0.99 & 13 & 1.74 \\
\hline 5 & Northwestern University & 167 & 2.34 & 120 & 5.79 & 57 & 1.41 & 34 & 4.56 \\
\hline 6 & University of Chicago & 155 & 2.17 & 130 & 6.27 & 44 & 1.09 & 33 & 4.43 \\
\hline 7 & Dartmouth College & 122 & 1.71 & 45 & 2.17 & 37 & 0.91 & 12 & 1.61 \\
\hline 8 & Yale University & 121 & 1.70 & 15 & 0.72 & 27 & 0.67 & 1 & 0.13 \\
\hline 9 & University of Virginia & 107 & 1.50 & 27 & 1.30 & 22 & 0.54 & 7 & 0.94 \\
\hline 10 & Cambridge University & 97 & 1.36 & 1 & 0.05 & 16 & 0.40 & 0 & 0.00 \\
\hline 11 & Princeton University & 97 & 1.36 & 1 & 0.05 & 17 & 0.42 & 0 & 0.00 \\
\hline 12 & University of Oxford & 95 & 1.33 & 1 & 0.05 & 25 & 0.62 & 1 & 0.13 \\
\hline 13 & New York University & 89 & 1.25 & 44 & 2.12 & 33 & 0.82 & 14 & 1.88 \\
\hline 14 & INSEAD & 88 & 1.23 & 79 & 3.81 & 35 & 0.87 & 17 & 2.28 \\
\hline 15 & University of Michigan & 82 & 1.15 & 18 & 0.87 & 34 & 0.84 & 8 & 1.07 \\
\hline 16 & Cornell University & 81 & 1.13 & 15 & 0.72 & 34 & 0.84 & 8 & 1.07 \\
\hline 17 & ParisTech & 75 & 1.05 & 5 & 0.24 & 41 & 1.01 & 7 & 0.94 \\
\hline 18 & Duke University & 74 & 1.04 & 17 & 0.82 & 21 & 0.52 & 6 & 0.81 \\
\hline 19 & University of Texas & 72 & 1.01 & 15 & 0.72 & 44 & 1.09 & 11 & 1.48 \\
\hline 20 & Georgetown University & 69 & 0.97 & 9 & 0.43 & 18 & 0.45 & 1 & 0.13 \\
\hline 21 & MIT & 66 & 0.92 & 16 & 0.77 & 16 & 0.40 & 1 & 0.13 \\
\hline 22 & UC Berkeley & 63 & 0.88 & 10 & 0.48 & 37 & 0.91 & 7 & 0.94 \\
\hline 23 & University of Notre Dame & 59 & 0.83 & 2 & 0.10 & 15 & 0.37 & 2 & 0.27 \\
\hline 24 & Stockholm School of Econ. & 58 & 0.81 & 1 & 0.05 & 12 & 0.30 & 1 & 0.13 \\
\hline 25 & Brown University & 53 & 0.74 & 0 & 0.00 & 20 & 0.49 & 0 & 0.00 \\
\hline 26 & UC Los Angeles & 53 & 0.74 & 28 & 1.35 & 30 & 0.74 & 10 & 1.34 \\
\hline \multirow[t]{4}{*}{27} & University of Illinois & 51 & 0.71 & 2 & 0.10 & 33 & 0.82 & 3 & 0.40 \\
\hline & Other & 3,297 & 46.19 & 382 & 18.42 & 3044 & 75.27 & 409 & 54.90 \\
\hline & No of Degrees & 7,138 & 100 & 2,074 & 100 & 4,044 & 100 & 745 & 100 \\
\hline & No of Individuals & 3,939 & & & & 2,599 & & & \\
\hline
\end{tabular}

in the same industry sector (which we validate with data up to 2015). ${ }^{17}$ The criteria are deliberately defined in a broad sense as we include various controls and matching procedures in the analysis to account for differences between the funds. ${ }^{18}$ This procedure leaves us with a set of around 750,000 counterfactual bidders and an average competition ratio of 247 from other funds (median: 243). While this number appears high, it is important to consider carefully what it measures. It represents all the funds that in principle could have identified the same target firm and invested as well. However, it is not saying that every fund has actually evaluated the company and/ or competed in a bidding process. ${ }^{19}$ Thus, the competition ratio measures the range of potential investors to whom the target would fit. The goal is to explain the access the winning fund has to the target via the use of a network measure. Metrick and Yasuda (2011) argue that as the private equity industry is maturing the level of competition among funds for potential deals is growing. We also observe such a trend in our data sample with a steadily increasing competition ratio (see Fig. 1). The competition ratio peaks in 2007 and remains on a high level throughout the financial crisis in which the private equity industry experienced lower fund raising activity. The trend of an increasing competition ratio (with the exception of the financial crisis) is not surprising as the number of buyout funds being raised also went up during our sample period. However, a comparable increase in the number of competing funds that also have an educational tie cannot be detected. Thus, if the hypothesis that educational ties increase the likelihood of winning an investment is true, then its importance should also increase with more competition.

\footnotetext{
17 The definitions follow the classification in the database and allow for a wide range of competition as we expect the educational ties to bridge across borders (e.g., country). Geographic region splits into Africa, Americas, Asia, and Europe. Industry sector differentiates between Business Products and Services (B2B), Consumer Products and Services (B2C), Energy, Financial Services, Healthcare, Information Technology, and Materials and Resources. We refer to Table 2 for related statistics.

${ }^{18}$ Outlining the difficulty to define criteria for a control group, Stuart and Yim (2010) even use an unrestricted comparison sample (based on all public firms in their sample).

${ }^{19}$ Fenn et al. (1997) note that some investment banks actively distribute their offering memorandums to up to 100 potential investors, while Gompers et al. (2016a) report that buyout managers consider on average 100 opportunities for every 3.6 closed deals (median: 3.0).
} 


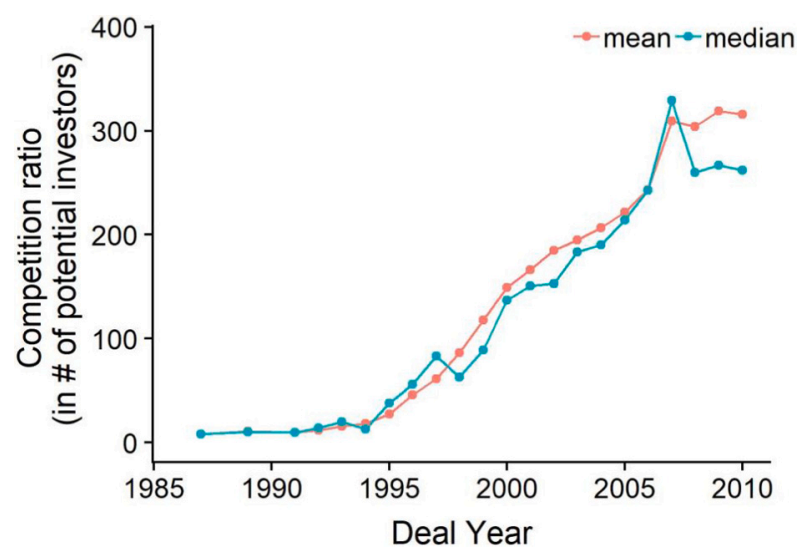

Fig. 1. Competition ratio by deal year.

The figure displays the development of the competition ratio between 1987 and 2010 by deal year as derived from the counterfactual approach presented in Section 2.5. The competition ratio is a number count and represents all the funds that in principle could have identified the same target firm. It measures the number of potential investors with similar target companies according to the criteria: (i) the deal takes place during a fund's investment period, which we define as the 5-year period following the vintage year, (ii) the fund makes at least one other investment in the same geographic region, and (iii) the fund makes at least one other investment in the same industry sector.. Mean and median figures refer to the average transaction as observed in the individual deal year.

To mitigate potential concerns about a high or increasing counterfactual investment ratio we present a variety of robustness checks on model specification, including several fixed effects settings. We also confirm our main results for both a random draw and propensity score matching (Section 4.1) as well as several approaches restricting the counterfactual sample (Section 4.2).

If educational ties are indeed an important driver for deal generation, we should observe this case more frequently than expected. Table 4 shows a cross-tabulation of actual versus counterfactual fund investments for educational ties (Panel A) and MBA ties (Panel B). Out of the 3051 investments in our sample, 453 have an educational tie, of which 130 have a tie based on an MBA degree. From these descriptive statistics we can see that the share of ties is twice as high for the actual investments (14.9\%) compared to the counterfactual sample (7.4\%). Similar results are found for MBA degrees (4.3\% for the actual deals compared to $2.4 \%$ in the counterfactual). This gives a first indication that educational networks may play a role for buyout funds when they source their investments.

\section{Empirical results}

\subsection{Educational ties in deal sourcing}

We first test whether the university background of private equity managers matters in terms of winning a deal via educational links to the CEO. ${ }^{20}$ Let index $j$ refer to the deals in the investment sample and index $i$ to the buyout funds that compete for each transaction. We define a multivariate logistic regression model with a binary response variable $Y_{i, j}$, which is set to one if fund $i$ wins deal $j$ (actual investment) and to zero otherwise (counterfactual investment), and probability $\pi_{i, j}$. The odds are then defined as the ratio of probability $\pi_{i, j}$ to its complement $1-\pi_{i, j}$, and the logit transformation gives the expected log of the odds as

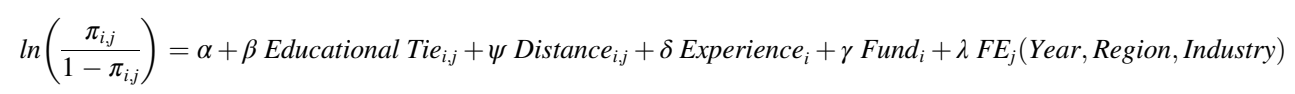

Since we focus on target firms that are actually taken over, we model the relative probabilities among bidding funds. Thus, we do not need to worry about the overall probability that the firm is acquired (Rousseau and Stroup (2015) use a similar setup for director movement). The variable of interest is the Educational Tie $e_{i, j}$ between the partners of fund $i$ and the CEO of target firm $j$. As the competitive situation relates to the point in time that a deal is made, the model is cross-sectional and, therefore, does not need a time index. Control variables include the partners' previous professional experience, fund characteristics, and the Distance $i, j$ between the target firm's headquarters and the closest fund office. ${ }^{21}$ We calculate geographical proximity as

$$
\text { Distance } \left._{i, j}=\min \left(\text { Haversine }_{\left(\text {Headquarter }_{j}\right.}, \text { Office }_{i, k}\right)\right)
$$

\footnotetext{
${ }^{20}$ We do not expect endogeneity concerns in this relationship due to simultaneity since the educational ties are formed many years before the individuals become partners (i.e., there is a clear timeline).

${ }^{21}$ We do not know the seller's identity in the deal to control for different types (e.g., blockholders).
} 


\section{Table 4}

Investment generation and educational ties.

The table shows the existence of an educational tie and an MBA tie, respectively. Actual investments are the buyout and growth transactions from buyout funds up to vintage year 2010 described in Table 2. Counterfactual investments represent potential transactions from buyout funds generated in the counterfactual approach that could have invested in the same company as well. To be included for a specific transaction, they are in their investment period at the time of the deal and have invested at least once in the same geographic region and industry sector. We refer to Section 2.5 for more details on the matching procedure. An educational tie exists if at least one of the fund partners has obtained a degree from the same academic institution as the $\mathrm{CEO}$ of the target company at the time of the transaction. An MBA tie exists if the fund partner and the CEO graduated from the same business school with an MBA degree.

\begin{tabular}{llll}
\hline Panel A: Educational Ties & & & \\
\hline \multirow{2}{*}{$\begin{array}{lll}\text { Investment } \\
\text { Actual }\end{array}$} & Educational Tie & Yes & Total \\
\cline { 2 - 4 } & 2,598 & 453 & 3,051 \\
\hline Counterfactual & $85.2 \%$ & $14.9 \%$ & $100 \%$ \\
\hline Total & 694,402 & 55,240 & 749,642 \\
& $92.6 \%$ & $7.4 \%$ & $100 \%$ \\
\hline \multirow{2}{*}{ Panel B: MBA Ties } & 697,000 & 55,693 & 752,693 \\
& $92.6 \%$ & $7.4 \%$ & $100 \%$ \\
\hline Investment & & & Total \\
\hline Actual & MBA Tie & & 3,051 \\
\cline { 2 - 4 } & No & Yes & $100 \%$ \\
\hline Counterfactual & 2,921 & 130 & 749,642 \\
\hline Total & $95.7 \%$ & $4.3 \%$ & $100 \%$ \\
\hline
\end{tabular}

which calculates the minimum geographical distance (in $\mathrm{km}$ ) between the headquarters of the target company involved in deal $j$ and the investment offices (index $k$ ) where at least one of the partners of fund $i$ is located. ${ }^{22}$ We include geographic distance as a control variable as the related literature reports a "home bias" for various kinds of investment funds (e.g., Sorensen and Stuart (2001, 2008), Chen et al. (2010), and Cumming and Dai (2010)).

The vector Experience $e_{i}$ measures the partner's exposure to consulting, accounting, and banking prior to joining the fund. Such experience may have opened up alternative networks to the partners. Another vector, Fund $d_{i}$, comprises committed capital and fund sequence number to capture organizational factors, which correlate with assets under management and institutional networks, and indicator variables for first-time funds and for funds based in the U.S. Finally, fixed effects are included for investment year, geographic region, and industry sector, which helps to address concerns about endogeneity due to an omitted variables bias. ${ }^{23}$ For example, fundfirm pairs with educational ties may also have close ties in terms of industry specialization or geographic location. Including investment year fixed effects allows us not only to control for year-specific events but also mitigates a potential bias related to inflated performance of non-realized deals (since the likelihood of observing an unrealized deal varies by investment year).

Table 5 reports our results. We find that when there is an educational tie the odds for winning a deal are about $79 \%$ higher (Column (1)). ${ }^{24}$ This is in line with the univariate evidence and represents an economically significant effect. If we restrict ties to the same degree type, graduation period, or both, the results remain significant (Columns (2) to (4)). In particular, if CEOs and private equity partners graduate within a 3-year window this strongly increases the odds of doing a deal, extending evidence from mutual funds' investments in public companies (Cohen et al. (2008)). Such ties likely incorporate direct social interaction and individuals of similar age as the protagonists were at the same university at the same time. In addition, business school ties show slightly lower coefficients compared to other degree types (Column (5)). MBA degrees are frequently observed in top management teams including the buyout fund partners in this study. Educational studies regularly describe the alumni network such a degree opens up as a pure side-benefit (Baruch and Peiperl (2000)), while our findings provide empirical evidence on their actual value. ${ }^{25}$

\footnotetext{
${ }^{22}$ The data only provides us with the investment office where the partner is based. Ideally, we would also be able to control for the partner's hometown in case it represents a different location to the office.

${ }^{23}$ We refer to Table 7 for alternative specifications of fixed effects (including target firms and investors).

24 The regression coefficient of 0.583 results in an odds ratio of 1.79 .

${ }^{25}$ The literature on mutual funds and corporate managers primarily associates MBA degrees with superior skills and management performance (e. g., Gottesman and Morey (2006a, 2006b)), while the venture capital literature tends to use them as a proxy for business and management education (e.g., Dimov and Shepherd (2005), Patzelt et al. (2009), Zarutskie (2010), Cai et al. (2013), Cai et al. (2016)).
} 


\section{Table 5}

Educational ties and the odds of winning a deal.

The table shows the results for cross-sectional regressions of a binary investment indicator on the existence of educational ties according to Eq. (1). The response variable equals one for actual and zero for counterfactual investments. The latter include for each transaction the buyout funds that are in investment period at the time of the deal and that have invested at least once in the same geographic region and industry sector. Educational ties are set to one when at least one of the fund partners graduated from the same academic institution as the CEO of the target firm and zero otherwise. Same type refers to an overlap in the academic degree (undergraduate, graduate, MBA, etc.) and Same time to a three-year window relative to the graduation year. An MBA tie exists if the partner and the CEO graduated from the same business school, while Non-MBA ties are the residual degrees. Geographic distance is measured between the headquarters of the target company and the nearest investment office, where a partner is based, and transformed to its logarithmic base. Consulting, Accounting, and Banking measure the share of partners with prior work experience in the respective industry. Fund size is the natural logarithm of the fund's committed capital and the sequence number is the natural logarithm on the number of funds the respective investor has already raised including the current one. First fund and U.S. fund are indicator variables that equal to one if the fund is the first fund for the investor and if the fund is based in the U.S., respectively. Each presented model includes vintage fixed effects on the investment's year, geographic region, and industry sector. Coefficients are estimated from a logit model and standard errors are clustered on investor level (in brackets).

Dependent variable: Investment Indicator

(1) (2) (3) (4) (5)

\begin{tabular}{|c|c|c|c|c|c|}
\hline Educational tie & $0.583^{* * *}(0.060)$ & & & & \\
\hline Educational tie (same type) & & $0.534 * * *(0.063)$ & & & \\
\hline Educational tie (same time) & & & $1.003 * * *(0.144)$ & & \\
\hline Educational tie (type, time) & & & & $0.959 * * *(0.154)$ & \\
\hline MBA tie & & & & & $0.539 * * *(0.092)$ \\
\hline Non-MBA tie & & & & & $0.601 * * *(0.068)$ \\
\hline Geographic Distance (log) & $-0.252^{* * *}(0.011)$ & $-0.255^{* * *}(0.011)$ & $-0.260 * * *(0.011)$ & $-0.260^{* * *}(0.011)$ & $-0.252^{* * *}(0.011)$ \\
\hline Accounting (\%) & $-0.066(0.148)$ & $-0.065(0.147)$ & $-0.066(0.146)$ & $-0.066(0.146)$ & $-0.067(0.148)$ \\
\hline Banking (\%) & $-0.006(0.067)$ & $-0.008(0.067)$ & $-0.010(0.067)$ & $-0.010(0.067)$ & $-0.006(0.067)$ \\
\hline Consulting (\%) & $0.164 *(0.089)$ & $0.169 *(0.089)$ & $0.178 * *(0.090)$ & $0.179 * *(0.090)$ & $0.165^{*}(0.089)$ \\
\hline Fund Size $(\log )$ & $0.070^{* * * *}(0.022)$ & $0.071 * * *(0.022)$ & $0.075^{* * *}(0.022)$ & $0.076 * * *(0.022)$ & $0.070^{* * *}(0.022)$ \\
\hline Fund Sequence (log) & $-0.103^{* *}(0.041)$ & $-0.104 * *(0.041)$ & $-0.097 * *(0.041)$ & $-0.097 * *(0.041)$ & $-0.103^{* * *}(0.041)$ \\
\hline First Fund (d) & $-0.205^{* * *}(0.065)$ & $-0.205^{* * *}(0.065)$ & $-0.202^{* * * *}(0.065)$ & $-0.203^{* * *}(0.065)$ & $-0.205^{* * *}(0.065)$ \\
\hline U.S. Fund (d) & $-0.089(0.057)$ & $-0.091(0.057)$ & $-0.079(0.057)$ & $-0.080(0.057)$ & $-0.089(0.057)$ \\
\hline F.E. Deal Year & Yes & Yes & Yes & Yes & Yes \\
\hline F.E. Region & Yes & Yes & Yes & Yes & Yes \\
\hline F.E. Industry & Yes & Yes & Yes & Yes & Yes \\
\hline Observations & 752,693 & 752,693 & 752,693 & 752,693 & 752,693 \\
\hline Pseudo $R^{2}$ & 0.066 & 0.065 & 0.065 & 0.064 & 0.066 \\
\hline
\end{tabular}

Note: $* p<0.1 ; * * p<0.05 ; * * * p<0.01$.

With regard to control variables, we see a strong negative effect associated with the geographic distance between the fund and the target firm. The professional experience variables for the management team, which measure the relative share of fund partners with previous experience in the consulting, accounting, and banking industry, show limited influence except for a slightly positive effect from consulting. Fund teams with a stronger focus on these sectors could have built alternative networks over time, or developed other approaches based on their specific experience (e.g., Siming (2014) reports that past employment at a financial adviser is beneficial for future mandates). In particular, partners who have spent their earlier professional life in a consulting firm may still enjoy access to industry networks established through their prior employer and their clients, respectively. We obtain similar results when controlling for previous investment experience in the same industry and region prior to the respective deal of the fund itself (see Table A.1 of the Internet Appendix). Controlling for these alternative ties supports our evidence on educational ties. ${ }^{26}$

Lastly, regarding fund-level controls we find significant effects associated with fund size and sequence number as well as the indicator variable for first-time funds. This is not surprising since larger funds typically also make more investments and may have built larger organizations to support deal sourcing, while first-time funds likely lack the latter. Larger fund teams are also likely to have more diversified backgrounds with regard to educational history, and thus may have access to a broader network (we control for team size in Section 3.2). On the other hand, we do not find any differential effect for U.S. based funds (the robustness checks in Section 4.2 confirm that educational ties in both geographic sub-samples remain significant).

\subsection{The exclusivity of educational ties}

After confirming the value of educational ties for the deal sourcing process in general, we seek to understand the features that make ties most useful and the relevance of the competitive setting the funds operate in. We start by investigating the exclusivity of the tie within the team and the potential relationship to the available team capacity. Evidence from CEO networks suggests that redundant ties do not provide additional value (Engelberg et al. (2013)). On the other hand, larger teams generally have more exposure to potential deal sources as well as more managerial capacity for the deal-sourcing process. In addition, we split the educational ties into

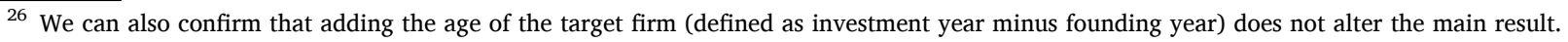


different subsets based on the school's position in academic rankings. We use the Times Higher Education (THE) World University Rankings of 2010 and argue that a university's position in the rankings is positively correlated with the magnitude and quality of its network. ${ }^{27}$ We interpret magnitude and quality in this context not with regard to the education offered but by the number of alumni in CEO positions that the fund partner can access.

Our findings are reported in Panel A of Table 6. First, we evaluate the strength of an individual tie by the incremental value of a redundant tie. We show that the likelihood that a transaction contains an educational tie of the acquiring buyout fund increases in the presence of redundant ties (Column (2)). This is contrary to the evidence on social ties in non-competitive environments and indicates that the ties provide value to the fund aside from a pure identification purpose. Second, team size is positively related to the likelihood of a success (Column (3)). We interpret team size as the overall capacity of the fund's management to pursue deal-sourcing efforts. We also confirm in Table A.2 of the Internet Appendix that normalizing the educational tie by team size leaves the resulting scaled tie highly significant (with and without team size as an additional control variable). Third, the ranking split shows that it is not only the ties from high-ranked schools that matter. The relatively rarer ties from low-ranked schools also exert an influence on the success rate (Column (4)). When we split the ties into several ranking classes, the increase in the odds ranges from $30 \%$ for top- 10 schools to above $300 \%$ for schools outside the top 100 . This finding may be driven by a lower level of competing funds that have access to the same network, which we investigate next.

We standardize the Educational Ti $e_{i, j}$ variable by its degree of exclusivity among the competing funds. Specifically, we divide the indicator variables by the number of counterfactual bidders that also have an educational tie to arrive at the following scaled version of educational ties

$$
\text { Scaled Educatioanl Tie } e_{i, j}=\frac{\text { Educational Tie }_{i, j}}{\sum_{i=1}^{n} \text { Educational Tie }_{i, j}}
$$

This effectively transforms the binary variables into a probability (values are bounded between zero and one). The scaled educational ties for transactions where the winning fund has a tie from a top-10 school has an average of only $1.8 \%$ (median: $1.2 \%$ ). The corresponding scaled educational tie for transactions involving non-top 100 schools has an average of 26.5\% (median: $14.3 \%$ ). The overall sample mean is $10.3 \%$ (median: $2.9 \%$ ). We re-estimate Eq. (1) and present results in Panel B of Table 6. We find that the probability of winning a deal increases the more exclusive the tie (Column (1)). The remaining results highlight one notable difference: the top-10 ranking group becomes insignificant indicating that the edge a tie provides to the fund diminishes if this is no longer a differentiating factor relative to competing funds (Column (4)). ${ }^{28}$

As noted earlier, the educational background of fund managers is dominated by a group of high ranked universities (see Table 3). On the other hand, CEOs graduate from a more diverse group of universities. Therefore, fund managers who attended less-represented schools can be of importance for deal generation.

\section{Robustness tests}

\subsection{Model specification}

It could be that the results from our counterfactual approach are biased by the selection procedure we apply. Therefore, to test the robustness of our results, we re-estimate our models in a fixed effects framework (following Bengtsson and Hsu (2015)) to ease concerns about omitted variables and different model specifications.

Table 7 presents our results. We split models between the full sample (Columns (1) to (4)) and a one-for-one random draw to counter the chance that results are driven by a high counterfactual ratio (Columns (5) to (8)). The latter is tested by Bengtsson and Hsu (2015) for the same reasons. ${ }^{29}$ The first specification in each block follows the same logistic regression formulation of deal generation success on educational ties from the main empirical results (see Eq. (1)). The second model uses OLS estimates but leaves everything else constant. Finally, the remaining two specifications change the fixed effects to the company and the investor level, respectively. While the educational tie remains highly significant, we observe a slightly better model fit using these fixed effects. This indicates that our previous results are, if anything, conservative, and the actual economic effects may be even higher. We use two-way cluster-robust standard errors on investor and company level for the OLS models as well as clustered standard errors at the investor level for the logistic regressions. The coefficients on educational ties (Panel A) and MBA ties (Panel B) are highly significant across all specifications.

\footnotetext{
${ }^{27}$ We verify our findings with the Academic Ranking of World Universities (ARWU) from the Center for World-Class Universities at Shanghai Jiao Tong University (also as of 2010).

28 Using the ARWU ranking the top 10 variable is weakly significant at the $10 \%$ level, while all other ranking classes remain highly significant and still exhibit increasing coefficients along the groups.

29 The creation of random simulation groups is also employed in Renneboog and Zhao (2014). In unreported results, we implemented a propensity score matching approach (which, for example, is used in Siming (2014)), based on the set of control variables and nearest neighbor to control for similarity in the characteristics between actual and counterfactual fund investments. In addition, in Section 4.2 we discuss two additional robustness tests using sub-samples to further restrict the number of counterfactuals. In all cases, we obtain qualitatively similar results.
} 


\section{Table 6}

Educational ties and the relevance of exclusivity.

The table extends the cross-sectional regressions of a binary investment indicator on the existence of educational ties from Table 5. A redundant tie indicates that more than one educational tie between the fund partners and the target firm CEO exists, while team size counts the partners in the fund's management team. Top- $X$ indicates the university's position in academic rankings (see Section 3.2 for more details). Panel $A$ shows evidence related to binary educational ties, which are set to one when at least one of the fund partners graduated from the same academic institution as the CEO of the target company and to zero otherwise. Panel $B$ normalizes the tie variables with the number of competing funds that have the same tie (see Eq. (3)). We refer to Table 5 for the list of control variables. Each model includes vintage fixed effects on the investment's year, geographic region, and industry sector. Coefficients are estimated from a logit model and standard errors are clustered on investor level (in brackets).

\begin{tabular}{|c|c|c|c|c|}
\hline & \multicolumn{4}{|c|}{ Dependent variable: Investment Indicator } \\
\hline & (1) & (2) & $(3)$ & (4) \\
\hline \multicolumn{5}{|l|}{ Panel A: Binary educational tie } \\
\hline Educational tie & $\begin{array}{l}0.583^{* * * *} \\
(0.060)\end{array}$ & $\begin{array}{l}0.437^{* * *} \\
(0.073)\end{array}$ & $\begin{array}{l}0.568^{* * * *} \\
(0.061)\end{array}$ & \\
\hline Redundant tie & & $\begin{array}{l}0.388^{* * * *} \\
(0.099)\end{array}$ & & \\
\hline Team size & & & $\begin{array}{l}0.011 * * * \\
(0.004)\end{array}$ & \\
\hline Educational tie (top-10) & & & & $\begin{array}{l}0.270^{* * * *} \\
(0.081)\end{array}$ \\
\hline Educational tie (top-11-30) & & & & $\begin{array}{l}0.433^{* * * *} \\
(0.114)\end{array}$ \\
\hline Educational tie (top-31-100) & & & & $\begin{array}{l}0.826^{* * * *} \\
(0.116)\end{array}$ \\
\hline Educational tie (above 100) & & & & $\begin{array}{l}1.229^{* * *} \\
(0.106)\end{array}$ \\
\hline \multicolumn{5}{|c|}{ Panel B: Scaled educational tie (by number of funds with similar tie) } \\
\hline Educational tie & $\begin{array}{l}2.340^{* * * *} \\
(0.194)\end{array}$ & $\begin{array}{l}2.082^{* * *} \\
(0.231)\end{array}$ & $\begin{array}{l}2.309 * * * \\
(0.196)\end{array}$ & \\
\hline Redundant tie & & $\begin{array}{l}2.573^{* * *} \\
(0.898)\end{array}$ & & \\
\hline Team size & & & $\begin{array}{l}0.014 * * * \\
(0.004)\end{array}$ & \\
\hline Educational tie (top 10) & & & & $\begin{array}{l}-0.007 \\
(0.943)\end{array}$ \\
\hline Educational tie (top-11-30) & & & & $\begin{array}{l}2.233^{* * * *} \\
(0.637)\end{array}$ \\
\hline Educational tie (top-31-100) & & & & $\begin{array}{l}2.178^{* * * *} \\
(0.431)\end{array}$ \\
\hline Educational tie (above 100) & & & & $\begin{array}{l}2.438^{* * *} \\
(0.216)\end{array}$ \\
\hline Control variables & Yes & Yes & Yes & Yes \\
\hline F.E. Deal Year & Yes & Yes & Yes & Yes \\
\hline F.E. Region & Yes & Yes & Yes & Yes \\
\hline F.E. Industry & Yes & Yes & Yes & Yes \\
\hline Observations & 752,693 & 752,693 & 752,693 & 752,693 \\
\hline
\end{tabular}

Note: ${ }^{*} p<0.1 ; * * p<0.05 ; * * * p<0.01$.

\subsection{Sub-sample robustness}

As a further robustness check, we present educational and MBA ties for various sub-samples in Table 8. We split the sample based on deal characteristics (e.g., geography, deal type) and fund attributes (e.g., vintage, size, performance). Each row in the table reports the coefficients and standard errors from two separate regressions, one for the educational ties (Column (1)) and one for the MBA ties compared to other types of academic degrees (Column (2)). The influence of ties remains across these various specifications.

In particular, we show that the effect persists when analyzing the competition among funds considering only investments that took place in Europe and North America, respectively. Results confirm the value of educational ties for both of these markets individually. ${ }^{30}$ We also differentiate among deal categories, where we find strong evidence for management buyouts/-ins and secondary buyouts. It may be that in these cases the CEO has a more active role in selecting its new owner, whereas normally the fund would be expected to be in the driving seat. In a secondary buyout, one fund sells its portfolio company to another fund (Degeorge et al. (2016)). This may

\footnotetext{
30 The number of deals for the remaining markets is relatively small (e.g., from Africa and Latin America). A sub-sample analysis on the remaining approx. 12,000 observations shows no significant influence of educational ties.
} 


\section{Table 7}

Robustness tests of model specification.

The table shows different variations of the regression setting of a binary investment indicator on the existence of educational ties according to Eq. (1). The response variable equals one for actual and zero for counterfactual investments. The latter include for each transaction the buyout funds that are in investment period at the time of the deal and that have invested at least once in the same geographic region and industry sector. Models 1 to 4 show results based on the full sample, while Models 5 to 8 use a one-for-one random draw on the counterfactual pairs. An educational tie exists if at least one of the partners graduated from the same university as the CEO of the target company. An MBA tie exists if both have obtained an MBA degree from the same business school. Non-MBA ties are the residual degrees. We refer to Table 5 for the definition of control variables. The table shows coefficient estimates and standard errors (in brackets). Models 1 and 5 show results from a logit model, the remaining models use Ordinary Least Squares (OLS) regressions with varying sets of fixed effects. Standard errors in the logistic model are clustered on the investor level, while the OLS models use twoway cluster-robust standard errors on investors and companies.

\begin{tabular}{|c|c|c|c|c|c|c|c|c|}
\hline & \multicolumn{8}{|c|}{ Dependent variable: Investment Indicator } \\
\hline & \multicolumn{4}{|l|}{ Full Sample } & \multicolumn{4}{|c|}{ Random draw } \\
\hline & (1) & $(2)$ & (3) & (4) & (5) & (6) & (7) & (8) \\
\hline & Logit & $\overline{O L S}$ & $\overline{O L S}$ & $\overline{O L S}$ & Logit & $\overline{O L S}$ & $\overline{O L S}$ & $\overline{O L S}$ \\
\hline \multicolumn{9}{|c|}{ Panel A: Academic degrees } \\
\hline Educational tie & $\begin{array}{l}0.583^{* * *} \\
(0.060)\end{array}$ & $\begin{array}{l}0.003^{* * *} \\
(0.0004)\end{array}$ & $\begin{array}{l}0.005^{* * *} \\
(0.001)\end{array}$ & $\begin{array}{l}0.003^{* * *} \\
(0.0004)\end{array}$ & $\begin{array}{l}0.677^{* * *} \\
(0.096)\end{array}$ & $\begin{array}{l}0.142^{* * *} \\
(0.017)\end{array}$ & $\begin{array}{l}0.267^{* * *} \\
(0.047)\end{array}$ & $\begin{array}{l}0.147^{* * * *} \\
(0.021)\end{array}$ \\
\hline Geo. Distance & $\begin{array}{l}-0.252^{* * *} \\
(0.011)\end{array}$ & $\begin{array}{l}-0.002^{* * *} \\
(0.0001)\end{array}$ & $\begin{array}{l}-0.002^{* * *} \\
(0.0001)\end{array}$ & $\begin{array}{l}-0.002^{* * *} \\
(0.0001)\end{array}$ & $\begin{array}{l}-0.331^{* * *} \\
(0.021)\end{array}$ & $\begin{array}{l}-0.068^{* * *} \\
(0.003)\end{array}$ & $\begin{array}{l}-0.123^{* * *} \\
(0.006)\end{array}$ & $\begin{array}{l}-0.064^{* * *} \\
(0.004)\end{array}$ \\
\hline Accounting (\%) & $\begin{array}{l}-0.079 \\
(0.150)\end{array}$ & $\begin{array}{l}-0.0004 \\
(0.001)\end{array}$ & $\begin{array}{l}-0.001 \\
(0.001)\end{array}$ & $\begin{array}{l}-0.002 \\
(0.001)\end{array}$ & $\begin{array}{l}-0.315 \\
(0.201)\end{array}$ & $\begin{array}{l}-0.066 \\
(0.044)\end{array}$ & $\begin{array}{l}-0.118 \\
(0.085)\end{array}$ & $\begin{array}{l}-0.141 \\
(0.102)\end{array}$ \\
\hline Banking (\%) & $\begin{array}{l}-0.007 \\
(0.067)\end{array}$ & $\begin{array}{l}-0.0001 \\
(0.0003)\end{array}$ & $\begin{array}{l}-0.0001 \\
(0.0003)\end{array}$ & $\begin{array}{l}-0.0001 \\
(0.001)\end{array}$ & $\begin{array}{l}-0.049 \\
(0.095)\end{array}$ & $\begin{array}{l}-0.011 \\
0.021)\end{array}$ & $\begin{array}{l}-0.024 \\
(0.044)\end{array}$ & $\begin{array}{l}-0.046 \\
(0.046)\end{array}$ \\
\hline Consulting (\%) & $\begin{array}{l}0.163^{*} \\
(0.089)\end{array}$ & $\begin{array}{l}0.001 * * \\
(0.0004)\end{array}$ & $\begin{array}{l}0.001 * * \\
(0.0004)\end{array}$ & $\begin{array}{l}0.001 \\
(0.001)\end{array}$ & $\begin{array}{l}0.124 \\
(0.129)\end{array}$ & $\begin{array}{l}0.028 \\
(0.029)\end{array}$ & $\begin{array}{l}0.054 \\
(0.060)\end{array}$ & $\begin{array}{l}0.023 \\
(0.055)\end{array}$ \\
\hline Fund Size $(\log )$ & $\begin{array}{l}0.070^{* * * *} \\
(0.022)\end{array}$ & $\begin{array}{l}0.0003^{* * *} \\
(0.0001)\end{array}$ & $\begin{array}{l}0.0003 * * * \\
(0.0001)\end{array}$ & $\begin{array}{l}0.001 * * * \\
(0.0002)\end{array}$ & $\begin{array}{l}0.130^{* * *} \\
(0.027)\end{array}$ & $\begin{array}{l}0.029^{* * *} \\
(0.006)\end{array}$ & $\begin{array}{l}0.051^{* * *} \\
(0.012)\end{array}$ & $\begin{array}{l}0.067^{* * * *} \\
(0.013)\end{array}$ \\
\hline Fund Seq. (log) & $\begin{array}{l}-0.103^{* *} \\
(0.041)\end{array}$ & $\begin{array}{l}-0.0005^{* *} \\
(0.0002)\end{array}$ & $\begin{array}{l}-0.001^{* * *} \\
(0.0002)\end{array}$ & $\begin{array}{l}0.003^{* * *} \\
(0.001)\end{array}$ & $\begin{array}{l}-0.106^{* *} \\
(0.049)\end{array}$ & $\begin{array}{l}-0.023^{* *} \\
(0.011)\end{array}$ & $\begin{array}{l}-0.042^{*} \\
(0.023)\end{array}$ & $\begin{array}{l}0.167^{* * * *} \\
(0.039)\end{array}$ \\
\hline First Fund (d) & $\begin{array}{l}-0.205^{* * *} \\
(0.065)\end{array}$ & $\begin{array}{l}-0.001^{* * *} \\
(0.0003)\end{array}$ & $\begin{array}{l}-0.001 * * * \\
(0.0003)\end{array}$ & $\begin{array}{l}0.0004 \\
(0.001)\end{array}$ & $\begin{array}{l}-0.358^{* * *} \\
(0.092)\end{array}$ & $\begin{array}{l}-0.079 * * * \\
(0.021)\end{array}$ & $\begin{array}{l}-0.120^{* * *} \\
(0.044)\end{array}$ & $\begin{array}{l}-0.00003 \\
(0.037)\end{array}$ \\
\hline U.S. Fund (d) & $\begin{array}{l}-0.089 \\
(0.057)\end{array}$ & $\begin{array}{l}-0.001^{* * *} \\
(0.0002)\end{array}$ & $\begin{array}{l}-0.001^{* * *} \\
(0.0002)\end{array}$ & $\begin{array}{l}-0.001 \\
(0.001)\end{array}$ & $\begin{array}{l}-0.053 \\
(0.084)\end{array}$ & $\begin{array}{l}-0.011 \\
(0.019)\end{array}$ & $\begin{array}{l}-0.008 \\
(0.038)\end{array}$ & $\begin{array}{l}-0.088^{*} \\
(0.052)\end{array}$ \\
\hline F.E. Deal Year & Yes & Yes & Yes & Yes & Yes & Yes & Yes & Yes \\
\hline F.E. Region & Yes & Yes & $\mathrm{n} / \mathrm{a}$ & Yes & Yes & Yes & $\mathrm{n} / \mathrm{a}$ & Yes \\
\hline F.E. Industry & Yes & Yes & $\mathrm{n} / \mathrm{a}$ & Yes & Yes & Yes & $\mathrm{n} / \mathrm{a}$ & Yes \\
\hline F.E. Company & No & No & Yes & No & No & No & Yes & No \\
\hline F.E. Investor & No & No & No & Yes & No & No & No & Yes \\
\hline $\begin{array}{l}\text { Observations } \\
R^{2}\end{array}$ & $\begin{array}{l}752,693 \\
0.066\end{array}$ & $\begin{array}{l}752,693 \\
0.005\end{array}$ & $\begin{array}{l}752,693 \\
0.007\end{array}$ & $\begin{array}{l}752,693 \\
0.009\end{array}$ & $\begin{array}{l}6,102 \\
0.151\end{array}$ & $\begin{array}{l}6,102 \\
0.109\end{array}$ & $\begin{array}{l}6,102 \\
0.197\end{array}$ & $\begin{array}{l}6,102 \\
0.255\end{array}$ \\
\hline \multicolumn{9}{|c|}{ Panel B: MBA versus other degrees } \\
\hline MBA tie & $\begin{array}{l}0.539 * * * \\
(0.092)\end{array}$ & $\begin{array}{l}0.003^{* * *} \\
(0.001)\end{array}$ & $\begin{array}{l}0.004^{* * *} \\
(0.001)\end{array}$ & $\begin{array}{l}0.003^{* * *} \\
(0.001)\end{array}$ & $\begin{array}{l}0.606^{* * *} \\
(0.146)\end{array}$ & $\begin{array}{l}0.135^{* * *} \\
(0.027)\end{array}$ & $\begin{array}{l}0.325^{* * *} \\
(0.089)\end{array}$ & $\begin{array}{l}0.143^{* * *} \\
(0.033)\end{array}$ \\
\hline Non-MBA tie & $\begin{array}{l}0.601^{* * *} \\
(0.068)\end{array}$ & $\begin{array}{l}0.004 * * * \\
(0.001)\end{array}$ & $\begin{array}{l}0.005^{* * * *} \\
(0.001)\end{array}$ & $\begin{array}{l}0.004^{* * * *} \\
(0.001)\end{array}$ & $\begin{array}{l}0.723^{* * *} \\
(0.116)\end{array}$ & $\begin{array}{l}0.154^{* * *} \\
(0.021)\end{array}$ & $\begin{array}{l}0.277^{* * * *} \\
(0.052)\end{array}$ & $\begin{array}{l}0.154^{* * * *} \\
(0.024)\end{array}$ \\
\hline Control variables & Yes & Yes & Yes & Yes & Yes & Yes & Yes & Yes \\
\hline Fixed Effects & Yes & Yes & Yes & Yes & Yes & Yes & Yes & Yes \\
\hline Observations & 752,693 & 752,693 & 752,693 & 752,693 & 6102 & 6102 & 6102 & 6102 \\
\hline$R^{2}$ & 0.066 & 0.005 & 0.007 & 0.009 & 0.130 & 0.094 & 0.178 & 0.239 \\
\hline
\end{tabular}

Note: $R^{2}$ for Logit models reports Nagelkerke's measure. * $p<0.1 ; * * p<0.05 ; * * * p<0.01$.

indicate that the fund manager and/or CEO reaches out to the network partner in order to facilitate the transaction. In contrast, there is no effect in public-to-private transactions where the influence of the overall board on decisions, and the more openly competitive nature of takeover contests, appears to weaken the influence of educational ties between the CEO and the private equity partners.

We also explore whether transactions involving a solo private equity fund (which occurs in $58 \%$ of our sample) differ from club deals (42\%). In a club deal, a private equity fund acquires a portfolio company together with other buyout funds and/or institutional investors. It is possible that our analysis may not be able to capture all existing ties between other members of the syndicate and the CEO of the portfolio company in club deals. However, we find that our results hold in both types of deal.

In Section 2.5, we discussed the average competition ratio of 247 in the full sample. To further increase confidence in our results, we split the sample into different buckets of competition levels. In 855 cases less than 150 funds compete with one another ( $28 \%$ of the sample), while there are 770 cases with between 150 and 250 competing funds ( $25 \%$ of the sample) and 1426 cases with more than 250 
Table 8

Robustness tests for sample selection.

The table shows the results for cross-sectional regressions of a binary investment indicator on the existence of educational ties according to Eq. (1) for various subsets of the deal data set. The dependent variable is an indicator that equals one for actual and zero for counterfactual investments. The latter include for each transaction the buyout funds that have been in investment period at the time of deal and that have invested at least once in the same geographic region and industry sector. Each cell represents a separate regression under the full model specification but only reports the coefficients for the educational ties and MBA ties, respectively. An educational tie exists if at least one of the partners graduated from the same academic institution as the CEO of the target company. An MBA tie exists if the fund partner and the CEO graduated from the same business school with an MBA. Control variables and fixed effects are used as in the original specifications (see Table 5, Specifications (1) and (5), respectively). The table depicts coefficients estimated from a logit model and standard errors clustered on investors (in brackets).

\begin{tabular}{|c|c|c|}
\hline & \multicolumn{2}{|c|}{ Dependent variable: Investment Indicator } \\
\hline & Educational tie & MBA tie \\
\hline Baseline model & $0.583^{* * *}(0.060)$ & $0.539 * * *(0.092)$ \\
\hline \multicolumn{3}{|l|}{ Deal characteristics } \\
\hline Deals in North America & $0.428^{* * *}(0.072)$ & $0.477^{* * *}(0.099)$ \\
\hline Deals in Europe & $0.872^{* * *}(0.111)$ & $0.754 * * *(0.256)$ \\
\hline MBO/MBI deals & $0.947^{* * *}(0.163)$ & $0.385(0.480)$ \\
\hline Secondary buyouts & $0.770^{* * *}(0.144)$ & $0.528 * *(0.255)$ \\
\hline Public to Private & $0.090(0.241)$ & $0.206(0.309)$ \\
\hline Solo deals & $0.714 * * *(0.079)$ & $0.589 * * *(0.135)$ \\
\hline Club deals & $0.395^{* * *}(0.089)$ & $0.450 * * *(0.150)$ \\
\hline$<150$ competing funds & $0.546^{* * *}(0.148)$ & $0.450^{* *}(0.218)$ \\
\hline $150-250$ competing funds & $0.499^{* * *}(0.098)$ & $0.730^{* * *}(0.151)$ \\
\hline$>250$ competing funds & $0.629^{* * *}(0.081)$ & $0.444 * * *(0.126)$ \\
\hline \multicolumn{3}{|l|}{ Fund characteristics } \\
\hline Post-2000 vintage & $0.612^{* * *}(0.068)$ & $0.556^{* * *}(0.106)$ \\
\hline Pre-2001 vintage & $0.473^{* * *}(0.122)$ & $0.488^{* *}(0.194)$ \\
\hline U.S. based & $0.444 * * *(0.071)$ & $0.518^{* * *}(0.099)$ \\
\hline Non-U.S. based & $0.782^{* * *}(0.109)$ & $0.458^{*}(0.257)$ \\
\hline First timer & $0.737^{* * *}(0.143)$ & $0.845^{* * *}(0.228)$ \\
\hline Non-first timer & $0.562^{* * *}(0.064)$ & $0.484 * * *(0.100)$ \\
\hline Large fund ${ }^{\dagger}$ & $0.581^{* * *}(0.065)$ & $0.538^{* * *}(0.099)$ \\
\hline Small fund ${ }^{\dagger}$ & $0.606^{* * *}(0.149)$ & $0.519 * *(0.264)$ \\
\hline High $\operatorname{IRR}^{\dagger}$ & $0.509^{* * *}(0.097)$ & $0.395^{* * *}(0.150)$ \\
\hline Low IRR ${ }^{\dagger}$ & $0.582^{* * *}(0.090)$ & $0.613 * * *(0.151)$ \\
\hline High TVPI ${ }^{\dagger}$ & $0.536^{* * *}(0.091)$ & $0.402^{* * *}(0.136)$ \\
\hline Low TVPI ${ }^{\dagger}$ & $0.519 * * *(0.110)$ & $0.680^{* * *}(0.167)$ \\
\hline
\end{tabular}

Note: ${ }^{\dagger}$ Above/below median value based on all buyout funds where the respective metric is available.

${ }^{*} p<0.1 ; * * p 0.05 ; * * * p<0.01$.

competing funds ( $47 \%$ of the sample). The impact of educational ties remains in each of these sub-samples.

With regard to fund attributes, we investigate pre-2001 and post-2000 vintage years yet find the effect to persist during both time periods. In recent years performance persistence has been reported to be lower than in earlier periods due to a maturing industry as well as the movement of individuals and knowledge between the investors (Braun et al. (2017)). The analysis also further indicates that results are not driven by unrealized deals, for which only interim performance measures are available.

The results also do not seem to be driven by U.S. funds or first-time funds as both sub-samples reveal consistent findings. Lastly, we split the fund sample between large and small funds as well as high and low performers (in terms of IRR and TVPI) to increase confidence in the general interpretation of our results. While this information is not available at the time the deal decision is made, it may indicate whether funds tend to win deals by over-paying (and subsequently have low return measures). However, the educational and MBA ties remain significant in all specifications.

Lastly, we perform another robustness test on the sub-sample of investments where deal size is available (see Table A.3 of the Internet Appendix). This comprises around half of the deals (1588 out of 3051). We calculate the average ticket size each fund invests in (by dividing fund size with the number of investments) and restrict the counterfactual sample to include only funds that fall within a band of $-50 \%$ to $+50 \%$ relative to deal size (adjusted for a $50 \%$ leverage assumption). This reduces the average competition ratio from 247 to 48 (median from 243 to 36). We re-run estimations from Table 5 and obtain qualitatively similar results. ${ }^{31}$

${ }^{31}$ We can also confirm that re-estimating the baseline model of Table 5 with deal size as an additional control variable does not alter the influence of the educational tie (see Table A.4 of the Internet Appendix). 


\section{Table 9}

Educational ties and subsequent investment performance.

The table shows results for cross-sectional regressions of deal performance on educational ties according to Eq. (4). The sample includes the subset of investments with performance data. The dependent variable represents the IRR and TVPI multiple of the investment, respectively. An educational tie exists if at least one of the fund partners graduated from the same academic institution as the CEO of the target company. Holding period describes the investment period for the respective fund whereas market return measures the equity market return for the same time frame in the region. We refer to Table 5 for the definition of control variables. The Heckman model shows the outcome equation. The selection equation contains the same set of independent variables, except for the educational tie, and, in addition, fixed effects for deal year, geographic region, and industry. The table depicts coefficients estimated with Ordinary Least Squares (OLS) and standard errors clustered on investor level (in brackets).

\begin{tabular}{|c|c|c|c|c|c|c|c|c|}
\hline & \multicolumn{8}{|c|}{ Dependent variable } \\
\hline & \multicolumn{4}{|l|}{ Deal IRR } & \multicolumn{4}{|c|}{ Deal TVPI } \\
\hline & (1) & (2) & (3) & (4) & (5) & (6) & (7) & (8) \\
\hline & OLS & OLS & OLS & Heckman & OLS & OLS & OLS & Heckman \\
\hline Educational tie & $\begin{array}{l}0.018 \\
(0.052)\end{array}$ & $\begin{array}{l}0.001 \\
(0.051)\end{array}$ & $\begin{array}{l}0.040 \\
(0.046)\end{array}$ & $\begin{array}{l}-0.013 \\
(0.064)\end{array}$ & $\begin{array}{l}0.087 \\
(0.269)\end{array}$ & $\begin{array}{l}0.108 \\
(0.270)\end{array}$ & $\begin{array}{l}0.190 \\
(0.269)\end{array}$ & $\begin{array}{l}0.009 \\
(0.302)\end{array}$ \\
\hline Geo. Dist. (log) & & $\begin{array}{l}-0.007 \\
(0.011)\end{array}$ & $\begin{array}{l}-0.012 \\
(0.010)\end{array}$ & $\begin{array}{l}-0.014 \\
(0.011)\end{array}$ & & $\begin{array}{l}-0.003 \\
(0.058)\end{array}$ & $\begin{array}{l}-0.013 \\
(0.056)\end{array}$ & $\begin{array}{l}-0.012 \\
(0.050)\end{array}$ \\
\hline Accounting (\%) & & $\begin{array}{l}-0.327^{* *} \\
(0.162)\end{array}$ & $\begin{array}{l}-0.449^{* * *} \\
(0.162)\end{array}$ & $\begin{array}{l}-0.499 * * * \\
(0.183)\end{array}$ & & $\begin{array}{l}-0.325 \\
(0.657)\end{array}$ & $\begin{array}{l}-0.557 \\
(0.657)\end{array}$ & $\begin{array}{l}-1.394 \\
(0.855)\end{array}$ \\
\hline Banking (\%) & & $\begin{array}{l}-0.020 \\
(0.098)\end{array}$ & $\begin{array}{l}-0.035 \\
(0.097)\end{array}$ & $\begin{array}{l}-0.108 \\
(0.095)\end{array}$ & & $\begin{array}{l}-0.173 \\
(0.464)\end{array}$ & $\begin{array}{l}-0.242 \\
(0.472)\end{array}$ & $\begin{array}{l}-0.460 \\
(0.427)\end{array}$ \\
\hline Consulting (\%) & & $\begin{array}{l}-0.119 \\
(0.165)\end{array}$ & $\begin{array}{l}-0.026 \\
(0.143)\end{array}$ & $\begin{array}{l}-0.039 \\
(0.139)\end{array}$ & & $\begin{array}{l}0.229 \\
(0.752)\end{array}$ & $\begin{array}{l}0.357 \\
(0.714)\end{array}$ & $\begin{array}{l}0.004 \\
(0.601)\end{array}$ \\
\hline Fund Size (log) & & $\begin{array}{l}-0.021 \\
(0.023)\end{array}$ & $\begin{array}{l}0.004 \\
(0.020)\end{array}$ & $\begin{array}{l}-0.057 \\
(0.053)\end{array}$ & & $\begin{array}{l}-0.415^{* * *} \\
(0.119)\end{array}$ & $\begin{array}{l}-0.336^{* * * *} \\
(0.114)\end{array}$ & $\begin{array}{l}-0.840^{* * *} \\
(0.243)\end{array}$ \\
\hline Fund Seq. (log) & & $\begin{array}{l}0.065^{* *} \\
(0.032)\end{array}$ & $\begin{array}{l}0.015 \\
(0.037)\end{array}$ & $\begin{array}{l}0.036 \\
(0.036)\end{array}$ & & $\begin{array}{l}0.078 \\
(0.161)\end{array}$ & $\begin{array}{l}-0.048 \\
(0.177)\end{array}$ & $\begin{array}{l}0.037 \\
(0.170)\end{array}$ \\
\hline First Fund (d) & & $\begin{array}{l}0.210 * \\
(0.118)\end{array}$ & $\begin{array}{l}0.188 \\
(0.118)\end{array}$ & $\begin{array}{l}0.238 * * \\
(0.109)\end{array}$ & & $\begin{array}{l}-0.463 \\
(0.473)\end{array}$ & $\begin{array}{l}-0.551 \\
(0.462)\end{array}$ & $\begin{array}{l}-0.213 \\
(0.470)\end{array}$ \\
\hline U.S. Fund (d) & & $\begin{array}{l}-0.007 \\
(0.047)\end{array}$ & $\begin{array}{l}0.006 \\
(0.049)\end{array}$ & $\begin{array}{l}0.030 \\
(0.077)\end{array}$ & & $\begin{array}{l}0.445 \\
(0.294)\end{array}$ & $\begin{array}{l}0.493^{*} \\
(0.293)\end{array}$ & $\begin{array}{l}0.924^{* *} \\
(0.369)\end{array}$ \\
\hline Holding Period (yrs) & & & $\begin{array}{l}-0.082^{* * *} \\
(0.013)\end{array}$ & $\begin{array}{l}-0.069 * * * \\
(0.009)\end{array}$ & & & $\begin{array}{l}-0.224^{* * *} \\
(0.045)\end{array}$ & $\begin{array}{l}-0.162^{* * *} \\
(0.043)\end{array}$ \\
\hline Market Return (\%) & & & $\begin{array}{l}2.265^{* * *} \\
(0.501)\end{array}$ & $\begin{array}{l}2.237 * * * \\
(0.339)\end{array}$ & & & $\begin{array}{l}4.160^{* *} \\
(1.755)\end{array}$ & $\begin{array}{l}4.567^{* * *} \\
(1.514)\end{array}$ \\
\hline F.E. Deal Year & Yes & Yes & Yes & No & Yes & Yes & Yes & No \\
\hline $\begin{array}{l}\text { Observations } \\
\text { Adjusted } R^{2} \\
\text { Inverse Mills Ratio }\end{array}$ & $\begin{array}{l}535 \\
0.128\end{array}$ & $\begin{array}{l}535 \\
0.127\end{array}$ & $\begin{array}{l}535 \\
0.292\end{array}$ & $\begin{array}{l}535 \\
0.201 \\
-0.091\end{array}$ & $\begin{array}{l}624 \\
0.052\end{array}$ & $\begin{array}{l}624 \\
0.069\end{array}$ & $\begin{array}{l}624 \\
0.113\end{array}$ & $\begin{array}{l}624 \\
0.078 \\
-1.510 * *\end{array}$ \\
\hline
\end{tabular}

Note: $* p<0.1 ; * * p<0.05 ; * * * p<0.01$.

\section{Educational ties and performance}

Having established the relevance of educational ties, in this section we investigate whether the performance of deals sourced from educational networks is better or worse than other deals.

On the one hand, educational ties could be beneficial to the fund if partners receive a financial favor from the CEO by lowering the price and increasing returns. However, this is unlikely since the board of directors of the target firm has to approve the deal. They in turn are liable to shareholders and hence will ensure a competitive price. On the other hand, fund managers with an educational tie to the CEO could simply prefer such transactions due to the relative easiness of the deal (as a result of the partner and the CEO knowing each other). In this case, they would not focus exclusively on the quality of the deal or may even be willing to trade easiness against quality. As a consequence, deals with educational ties might underperform deals without such a tie. However, private equity partners are incentivized to maximize returns via carried interest structures.

Univariate evidence suggests that performance is not statistically different for deals with and without a tie (average IRR of $18.9 \%$ versus $19.7 \%$, TVPI of $3.03 \times$ versus $2.98 \times$ ). While both the IRR and the TVPI sub-sample have slightly higher ratios of educational ties (18.9\% and 19.1\%), we also confirm that the findings on the impact of educational ties to win the deal hold in the sub-samples (in unreported regressions based on the specifications from Table 7). The data we obtained for our analysis comes primarily from one large investor and is therefore conditional on the investor's particular investment strategy. Thus, we use a Heckman selection model to reduce a potential bias from the sampling approach. The selection equation contains the same independent variables, except for the educational tie and, in addition, fixed effects for deal year, geographic region, and industry sector. We estimate the impact on performance using an OLS regression with the following cross-sectional specification.

$$
\text { Performance }_{j}=\alpha+\beta \text { Educational Tie }_{j}+\delta \text { Experience }_{j}+\gamma \text { Fund }_{j}+\xi \text { Investment }_{j}+\lambda \text { Year }_{j}+\varepsilon_{j}
$$

Each observation represents one deal and the dependent variable Performance ${ }_{j}$ is represented by either IRR or the TVPI multiple. 
Control variables are identical to previous specifications with the addition of two investment-related variables, namely the holding period and the prevailing market return. The former measures time between entry and exit and the latter is a total return index over the lifetime of the investment. ${ }^{32}$ Finally, we add deal-year fixed effects to account for performance differences related to the deal origination period. ${ }^{33}$

First empirical evidence on the impact of network structures on deal-level returns is given in Table 9. Our findings do not show a significant effect for the educational ties supporting the argument that educational ties are only useful to close a transaction but neutral with regard to performance. Controlling for the length of the holding period and the market return shows negative and positive evidence, respectively. Due to the time sensitivity of investments, the negative (positive) impact of holding period (market return) is not surprising as private equity exits are highly influenced by the overall economic environment. This complements recent investigations on the drivers of deal level performance (e.g., Achleitner et al. (2010), Acharya et al. (2013), and Braun et al. (2017)). While our results suggest that educational ties do not have a significant impact on investment performance, the analysis is limited by the sparse availability of performance data. Ideally, one would test the effect with a much larger sample and also integrate entry-level valuations as well as controls for post-deal performance, e.g., through the use of detailed cash-flow data, into the analysis. However, such data is not available to us and thus we leave a final judgment on performance open to future research.

\section{Concluding remarks}

We build on the literature on the relevance of social ties using a novel data set based on the profiles of private equity fund managers and target firm CEOs. Our analysis reveals that deals which are successfully closed by a buyout fund are more likely to contain an educational tie as compared to a set of benchmark funds, which did not acquire the same company. Educational ties may both influence the investment choice of buyout funds and/or increase the likelihood of a successful transaction closing. During their competitive sourcing process, the existence of such ties eases identification and access to potential acquisition targets. This confirms earlier notions in the literature that personal and professional networks are an important channel for investors to identify target firms.

In addition, we find that the impact of an educational tie is higher when it gives (more) exclusivity to the acquiring fund relative to the degree of competition in the market. As academic degrees of senior managers in the private equity industry are concentrated in a small set of schools, the existence of educational ties is an important differentiating factor in consummating a deal. However, we find no evidence that the deals involving educational ties perform any better or worse than others.

\section{Appendix A. Supplementary data}

Supplementary data to this article can be found online at https://doi.org/10.1016/j.jcorpfin.2020.101740.

\section{References}

Acharya, V.V., Gottschalg, O.F., Hahn, M., Kehoe, C., 2013. Corporate governance and value creation: evidence from private equity. Rev. Financ. Stud. 26 (2), 368-402.

Achleitner, A.-K., Braun, R., Engel, N., Figge, C., Tappeiner, F., 2010. Value creation drivers in private equity buyouts: empirical evidence from Europe. J. Private Equity 13 (2), 17-27.

Allen, F., Babus, A., 2009. Networks in finance. In: The network challenge: Strategy, profit, and risk in an interlinked world. Wharton School Publishing, pp. 367-382. Chap. 21.

Baruch, Y., Peiperl, M., 2000. The impact of an MBA on graduate careers. Hum. Resour. Manag. J. 10 (2), 69-90.

Bengtsson, O., Hsu, D.H., 2015. Ethnic matching in the U.S. venture capital market. J. Bus. Ventur. 30 (2), $338-354$.

Braun, R., Jenkinson, T., Stoff, I., 2017. How persistent is private equity performance? Evidence from deal-level data. J. Financ. Econ. 123 (2), 273-291.

Brown, R., Gao, N., Lee, E., Stathopoulos, K., 2012. What are friends for? CEO networks, pay and corporate governance. In: Corporate Governance. Springer-Verlag, Berlin Heidelberg, pp. 287-307.

Brown, G.W., Harris, R.S., Jenkinson, T., Kaplan, S.N., Robinson, D., 2015. What Do Different Commercial Data Sets Tell us about Private Equity Performance? (Working Paper).

Butler, A.W., Gurun, U.G., 2012. Educational networks, mutual fund voting patterns, and CEO compensation. Rev. Financ. Stud. 25 (8), $2533-2562$.

Cai, Y., Sevilir, M., 2012. Board connections and M\&A transactions. J. Financ. Econ. 103 (2), 327-349.

Cai, Y., Sevilir, M., Tian, X., 2013. Do Entrepreneurs Make Good VCs? Working Paper, AFA 2013 San Diego Meetings Paper.

Cai, Y., Gantchev, N., Sevilir, M., 2016. Business School Networks and VC-Backed Startups (Working Paper).

Chen, H., Gompers, P., Kovner, A., Lerner, J., 2010. Buy local? The geography of venture capital. J. Urban Econ. 67 (1), $90-102$.

Cohen, L., Malloy, C.J., 2010. The power of alumni networks. Harv. Bus. Rev. 88 (10), 34.

Cohen, L., Frazzini, A., Malloy, C., 2008. The small world of investing: board connections and mutual fund returns. J. Polit. Econ. 116 (5), $951-979$.

Cohen, L., Frazzini, A., Malloy, C., 2010. Sell-side school ties. J. Financ. 65 (4), 1409-1437.

Cumming, D., Dai, N., 2010. Local bias in venture capital investments. J. Empir. Financ. 17 (3), 362-380.

Cumming, D., Walz, U., 2010. Private equity returns and disclosure around the world. J. Int. Bus. Stud. 41 (4), $727-754$.

\footnotetext{
${ }^{32}$ For North American deals, we use the MSCI North America, for European deals the MSCI Europe, and for the remaining investments the MSCI World (all retrieved from Thomson Reuters in USD).

${ }^{33}$ We also add the disclosure index developed in La Porta et al. (2006) to control for legal and institutional differences, and obtain similar results (see Table A.5 of the Internet Appendix). We refer to Cumming and Walz (2010) for a broader discussion of these factors in the context of private equity funds.
} 
Degeorge, F., Martin, J., Phalippou, L., 2016. On secondary buyouts. J. Financ. Econ. 120 (1), 124-145.

Dimov, D., Shepherd, D.A., 2005. Human capital theory and venture capital firms: exploring "home runs" and "strike outs". J. Bus. Ventur. 20 (1), 1-21.

Engelberg, J., Gao, P., Parsons, C.A., 2012. Friends with money. J. Financ. Econ. 103 (1), 169-188.

Engelberg, J., Gao, P., Parsons, C.A., 2013. The price of a CEO's rolodex. Rev. Financ. Stud. 26 (1), 79-114.

Fenn, G.W., Liang, N., Prowse, S., 1997. The private equity market: an overview. Financ. Mark. Inst. Instrum. 6 (4), 1-106.

Fracassi, C., Tate, G., 2012. External networking and internal firm governance. J. Financ. 67 (1), 153-194.

Gompers, P.A., Xuan, Y., 2009. Bridge Building in Venture Capital-Backed Acquisi- Tions (Working Paper).

Gompers, P.A., Kaplan, S.N., Mukharlyamov, V., 2016a. What do private equity firms say they do? J. Financ. Econ. 121 (3), $449-476$.

Gompers, P.A., Mukharlyamov, V., Xuan, Y., 2016b. The cost of friendship. J. Financ. Econ. 119 (3), 626-644.

Gottesman, A.A., Morey, M.R., 2006a. Does a better education make for better managers?. In: An Empirical Examination of CEO Educational Quality and Firm

Performance (Working Paper).

Gottesman, A.A., Morey, M.R., 2006b. Manager education and mutual fund performance. J. Empir. Financ. 13 (2), $145-182$.

Granovetter, M.S., 1973. The strength of weak ties. Am. J. Sociol. 78 (6), 1360-1380.

Granovetter, M.S., 1983. The strength of weak ties: a network theory revisited. Sociol. Theor. 1, 201-233.

Granovetter, M.S., 2005. The impact of social structure on economic outcomes. J. Econ. Perspect. 19 (1), 33-50.

Harris, R.S., Jenkinson, T., Kaplan, S.N., Stucke, R., 2014. Has persistence persisted in private equity?. In: Evidence from Buyout and Venture Capital Funds (Working Paper).

Harris, R.S., Jenkinson, T., Kaplan, S.N., 2016. How do private equity investments perform compared to public equity? J. Invest. Manag. 14 (3), $14-37$.

Hochberg, Y.V., Ljungqvist, A., Lu, Y., 2007. Whom you know matters: venture capital networks and investment performance. J. Financ. 62 (1), $251-301$.

Hochberg, Y.V., Ljungqvist, A., Lu, Y., 2010. Networking as a barrier to entry and the competitive supply of venture capital. J. Financ. 65 (3), $829-859$.

Hochberg, Y.V., Lindsey, L.A., Westerfield, M.M., 2015. Resource accumulation through economic ties: evidence from venture capital. J. Financ. Econ. 118 (2), 245-267.

Ishii, J., Xuan, Y., 2014. Acquirer-target social ties and merger outcomes. J. Financ. Econ. 112 (3), 344-363.

Jääskeläinen, M., Maula, M., 2014. Do networks of financial intermediaries help reduce local bias? Evidence from cross-border venture capital exits. J. Bus. Ventur. 29 (5), 704-721.

Kuhnen, C.M., 2009. Business networks, corporate governance, and contracting in the mutual fund industry. J. Financ. 64 (5), 2185-2220.

La Porta, R., Lopez-de-Silanes, F., Shleifer, A., 2006. What works in securities Laws? J. Financ. 61 (1), 1-32.

Ljungqvist, A., Richardson, M., Wolfenzon, D., 2009. The Investment Behavior of Buyout Funds: Theory and Evidence (Working Paper).

Metrick, A., Yasuda, A., 2010. The economics of private equity funds. Rev. Financ. Stud. 23 (6), 2303-2341.

Metrick, A., Yasuda, A., 2011. Venture capital and other private equity: a survey. Eur. Financ. Manag. 17 (4), $619-654$.

Morkoetter, S., Wetzer, T., 2015. Private Equity Performance in M\&A Transactions: Empirical Evidence from the Buy and Sell Side. Working Paper, No. 2015/22. Swiss Institute of Banking and Finance.

Patzelt, H., Zu Knyphausen-Aufseß, D., Fischer, H.T., 2009. Upper echelons and portfolio strategies of venture capital firms. J. Bus. Ventur. 24 (6), 558-572.

Phalippou, L., 2007. Investing in Private Equity Funds: A Survey. The Research Foundation of CFA Institute.

Preqin, 2016. Private. Equity Spotlight 12 (7), 1-23.

Renneboog, L., Zhao, Y., 2014. Director networks and takeovers. J. Corp. Finan. 28 (C), 218-234.

Rousseau, P.L., Stroup, C., 2015. Director histories and the pattern of acquisitions. J. Financ. Quant. Anal. 50 (4), $671-698$.

Siming, L., 2014. Your former employees matter: private equity firms and their financial advisors. Rev. Financ. 18 (1), $109-146$.

Sorensen, O., Stuart, T.E., 2001. Syndication networks and the spatial distribution of venture capital investments. Am. J. Sociol. 106 (6), $1546-1588$.

Sorensen, O., Stuart, T.E., 2008. Bringing the context back in: settings and the search for syndicate partners in venture capital investment networks. Adm. Sci. Q. 53 (2), 266-294.

Stuart, T.E., Yim, S., 2010. Board interlocks and the propensity to be targeted in private equity transactions. J. Financ. Econ. 97 (1), $174-189$.

Sunesson, D.T., 2009. Alma Mater Matters: The Value of School Ties in the Venture Capital Industry (Working Paper).

Teten, D., Farmer, C., 2010. Where are the deals? Private equity and venture capital Funds' best practices in sourcing new investments. J. Private Equity 14 (1), 32-53.

Wegener, B., 1991. Job mobility and social ties: social resources, prior job, and status attainment. Am. Sociol. Rev. 56 (1), $60-71$.

Wu, B., 2011. Shall we Dance? Syndication, Social Network, and Performance: Evidence from Leveraged Buyout Investments. Working Paper. Yonsei University. Zarutskie, R., 2010. The role of top management team human capital in venture capital markets: evidence from first-time funds. J. Bus. Ventur. 25 (1), 155-172. 